\title{
Connected Histories: the Dynamics of Bronze Age Interaction and Trade 1500-1100 BC
}

\author{
By KRISTIAN KRISTIANSEN ${ }^{1}$ and PAULINA SUCHOWSKA-DUCKE ${ }^{2}$
}

The Bronze Age was the first epoch in which societies became irreversibly linked in their co-dependence on ores and metallurgical skills that were unevenly distributed in geographical space. Access to these critical resources was secured not only via long-distance physical trade routes, making use of landscape features such as river networks, as well as built roads, but also by creating immaterial social networks, consisting of interpersonal relations and diplomatic alliances, established and maintained through the exchange of extraordinary objects (gifts). In this article, we reason about Bronze Age communication networks and apply the results of use-wear analysis to create robust indicators of the rise and fall of political and commercial networks. In conclusion, we discuss some of the historical forces behind the phenomena and processes observable in the archaeological record of the Bronze Age in Europe and beyond.

Keywords: Bronze Age communication networks, agents, temperate Europe, Mediterranean Basin

THE EUROPEAN BRONZE AGE AS A COMMUNICATION NETWORK: HISTORICAL \& THEORETICAL FRAMEWORK

Among the characteristics that might compel archaeologists to label the Bronze Age a 'formative epoch' in European history, the density and extent of the era's exchange and communication networks should perhaps be regarded as the most significant. During the Bronze Age, cultural, social, and political formations of a new kind and magnitude came into existence and transformed Europe into a connected economic zone, where intense and dynamic relations between local, regional, and 'global' processes of change coincided with increased social connectivity and mobility. New and larger regional cultural zones, such as Nordic or Atlantic, emerged as a result of the distribution of metal and the regularity of social interaction, while at the same time inter-regional trade crosscut and linked such regional configurations together, often characterised by international weapon types. At the same time, an increasing diversity of local cultural and political configurations or chiefdoms can be detected

\footnotetext{
${ }^{1}$ University of Gothenburg, Sweden, kristian. kristiansen@archaeology.gu.se

${ }^{2}$ Adam Mickiewicz University, Poznan, Poland, pausuc@amu.edu.pl
}

by small variations in ornaments and weapons (Kristiansen 2014).

Initially driven by the necessity to gain access to remote resources and technological skills, Bronze Age societies established communication links that ranged from the Baltic to the Mediterranean and from the Atlantic to the Black Sea (cf. Sherratt 1993; Kristiansen \& Larsson 2005; Suchowska 2009). They incorporated natural pathways such as coastal sea routes, rivers, and mountain passes, as well as trails and built roads, to form a 'network of networks' that facilitated a great diversity of physical modes and motivations for transport and travelling. Indeed, one must take care to differentiate between the material components of the network, such as roads and river transport links, and the immaterial or social ones. The latter must have been embedded in the former, but are exceedingly hard to reconstruct in the absence of written sources, as is the case for large parts of the European Bronze Age. Alternatively, one might think of physical networks as the conductors of past social behaviour. Thus, the gradual introduction of bronze and bronze-working technologies into all spheres of life - from weapons and ornaments to working tools such as axes, and agrarian tools such as sickles - had social and political implications. As all communities 
became dependent upon regular supplies of bronze, new social institutions were established that secured such regular supplies on a year to year basis, perhaps even on a month to month basis. New forms of organised transport had to be developed, both at sea and on land, as well as political alliances and confederations that guaranteed the safety of traders and their companies. A stop in supplies would mean severe long-term economic and political consequences, and therefore had to be avoided. Consequently we see the emergence of new forms of stable long-distance alliances and confederacies.

Chiefly confederacies were recently subject to a comparative study by Blair Gibson (2011), who used evidence from Celtic Iron Age Ireland, Archaic Greece, Korea, and Iran, and from ethnographic cases in the Pacific. Confederacies could be employed in the formation of a larger composite chiefdom, geographically coherent, as in Ireland, or they could be employed to link chiefdoms together in linear geographical space, as with nomadic or maritime confederacies, in order to secure trade. Bronze Age and Viking Age confederacies belong rather in the latter category (Gibson 2011). Gibson (2011, 217) defined confederacies as follows: 'A Chiefdom confederacy consists of a number of genealogically related and unrelated chiefdoms which were unified through coercion or common agreement'. Once established, networks became catalysts of cultural exchange that led to profound social change throughout the Mediterranean Basin and temperate Europe. In the Bronze Age, routes for the supply of raw materials, and later more refined trading goods, created the basis for individuals to move across the continent, taking on many different roles such as travelling craftsmen, warriors/ mercenaries, diplomats, and perhaps explorers. It is at this point that we can truly speak of 'travelling cultures' and an interconnected 'globalised' world (Clifford 1992; Kristiansen in press). A major motivating force in the maintaining of interregional networks was linked to the competitive advances that certain regions possessed (Earle et al. 2015). Baltic amber was craved in the eastern Mediterranean, and once South Scandinavia was able to take advantage of this situation, its wealth increased to unprecedented levels. Likewise, Cornwall possessed tin, the Carpathian region salt mines, the steppes supplied good horses, etc. In short, no region was able to maintain their social system without being part of the larger inter-regional networks that supplied the goods everyone needed.

For a holistic perspective on the connected world of the Bronze Age, it is important to keep in mind that physical networks are largely self-organising and selfreplicating structures once their institutional framework is in place. However, they are also highly dynamic and unstable. Competition must have arisen between different regions in Europe, or even between different local communities, to secure a better place in the network. Warriors were thus increasingly important for their role in protecting trade missions, while at the same time they were potentially disruptive.

In this article, we wish to shed some light on these opposing forces of 'trade monopolies/peacekeeping alliances' versus 'competition/disruption' in the distribution and operation of trade networks/political alliances. We are thus only in partial agreement with Knappett (2011) as we contend that self-organisation can only be understood within a specific historical framework of operating institutions. They provide the necessary social and political framework, in short the political economy (Earle 2002). To illuminate this we have chosen the period 1500-1100 BC as our case study, as this period saw the formation of a stable international trade network that connected the Nordic amber-rich zone with southern Germany and further to the western Mediterranean. However, during the 13th century this trade network was disrupted and collapsed, and only after some time was it replaced by a new network that connected the Nordic zone to eastern Central Europe, and further on to the Aegean. We will trace this changeover through an analysis of use on full-hilted swords and flange-hilted swords, as well as through an analysis of the distribution of Naue II swords, which became the dominant warrior sword after $1300 \mathrm{BC}$.

\section{THE FORMATION OF INTER-CONNECTED ECONOMIES AND VALUES IN EUROPE \& BEYOND}

The 15th-13th centuries BC were a period of intensive socio-political development, connectivity, and longdistance mobility. How complex these cross-cultural relations were is particularly visible in the eastern Mediterranean, where communication and trade flourished despite a growing tension between Egypt and the Hittite cities over the Levant (Astour 1981). In the Aegean, this was the period in which the Mycenaeans took over long-distance trade routes from the Minoans and underwent a period of great cultural and economic expansion characterised by excessive consumption (Cline 2009; Burns 2010; Steel 2013). According to the written sources, merchants, sailors, craftsmen, and diplomats, as well as warriors/mercenaries providing 


\section{K. Kristiansen \& P. Suchowska-Ducke CONNECTED HISTORIES 1500-1100 BC}

security, were meeting in many ports-of-trade located on the Near Eastern coast. For instance, in Ugarit in the Levant, foreigners from Cyprus, the Aegean, Egypt, Anatolia, Canaan, and Assyria resided temporarily or permanently to conduct their trades (Astour 1981).

A good impression of the scale of the exchange is provided by written sources that give the quantities and sizes of merchant ships. In Ugaritic texts we find references to vessels carrying 450-500 tons of cargo and fleets composed of several such ships (Casson 1995, 36). The cargo of the Late Bronze Age shipwrecks of Uluburun, Cape Gelidonya, and Point Iria represent various types of trade. Uluburun indicates a ceremonial and commercial exchange on an official royal trip (Pulak 2001), whereas Cape Gelidonya shows evidence of a private enterprise undertaken by merchants engaged in freelance metal trade (Bass 1991). The cargo of Point Iria, on the other hand, consisting of Cypriot and Aegean storage vessels, is most likely that of a trader in local produce (Lolos 1999).

Such commercial trade endeavours, whether local or international, were facilitated by political negotiations, as is evidenced in the Armana diplomacy between the Great Powers of the time (Astour 1981; Moran 1992; Cohen \& Westbrook 2000). Most crucially from a European perspective, the rising Mycenaean kingdom (or kingdoms) was part of this high-level political network that secured trade, whether in the form of monopolies in certain goods or access to harbours and markets. The so-called 'Aegean List' found near the Valley of the Kings, frescoes from the Cult Centre at Mycenae, and archaeological finds with pharaoh's cartouches support a likely scenario that an official Egyptian embassy was sent to the Aegean during the reign of Amenhotep III, possibly directed specifically towards Mycenae (Wachsmann 1987; Marinatos 1988; Cline 2014, 44 ff). However, there is also substantial textual evidence for the establishment of economic embargoes and other forms of political control over the activity of merchants and diplomats operating within the Mediterranean Basin (Cline 1991; Moran 1992). All this confirms the complexity of the trading network, which connected the Mediterranean world during the second half of the 2 nd millennium BC.

Although it seems that the socio-political situation in temperate Europe was less complex than in the Mediterranean Basin, there is no doubt that it, too, saw a period of consolidation and greater regularity of cross-cultural communication and long-distance exchange, particularly in the 15 th and into the 13th century BC (Sherratt 1993; Kristiansen \& Larsson 2005). At this time the western Mediterranean became the focus of new direct trade with the expanding Tumulus Culture of western Central Europe, which secured direct connections to Jutland and its sources of amber. The archaeological evidence shows that the Tumulus societies were in contact with the Aegean city-states through the exchange of amber and metal items, and also perhaps of perishable goods (Fig. 1). It created new wealth in the Nordic Bronze Age and led to the formation of a specific Nordic style based on Mycenaean templates. New habits from shaving to sitting on campstools were adopted (Kaul 2013).

In the 13th century $\mathrm{BC}$, long-distance communication between temperate Europe and the Mediterranean intensified and became more direct, as the Mycenaeans grew more interested in their northern frontier. The Balkans, on the periphery of the Aegean world, became the destination of the political and economic expansion of the Mycenaeans, as is visible for instance in the Assiros and Kastanas settlements (Wardle 1993; Lichardus et al. 2002; Aslaksen 2013). Contacts with societies of Italy were also maintained and extended as far as the highly developed Terramare Culture of the Po Valley (Vianello 2005; 2009). The Circum-Alpine region was strongly connected with the important centres of the Carpathian Basin (Palincas 2007; Dietrich 2010), and it was this hub of innovation and resources that allowed the communications to extend further north, all the way into Scandinavia (Kristiansen 1987). For now, this trade was dominated by eastern Central Europe, and we shall later analyse the consequences this had for the former western Central European tumulus trade network.

In the Mediterranean, this period of prosperity ended unexpectedly in the 12th century BC, when significant political, social, and economic changes occurred (Sandars 1983; Drews 1993; Cline 2009; 2014; Wachsmann 2013). This caused a partial collapse of exchange and communication networks and a decline of political and economic entities such as the Mycenaean Culture, the Hittite Empire, and the cities of the Levant (eg, Ugarit), and weakened Egypt and Mesopotamia. On the other hand, this situation apparently created new opportunities for territories lying in the so-called 'marginal zone' (for instance in Central Europe) and for some enclaves like Cyprus, where new bronzeworking centres developed (Muhly 1992; Vianello 2005). This process was partly enabled by a collapse of centralised administrative centres that freed technological 


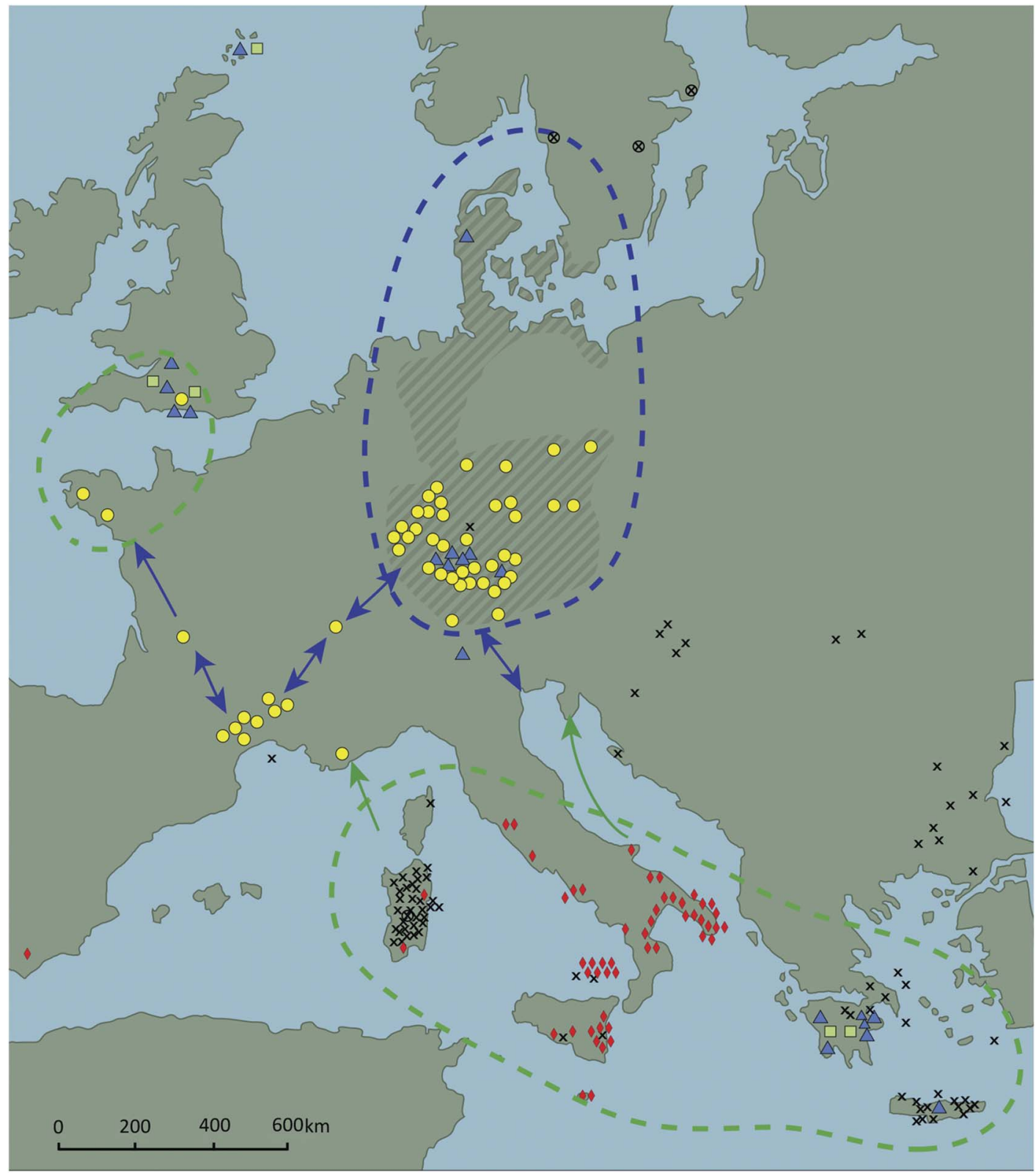

\section{Distribution of amber spacer-plates}

$\square$ end pieces with converging perforation

$\Delta$ complex bored with V-perforations

○ all other types $x$ oxhide ingots

$\otimes$ oxhide ingots on rock art

- Mycenean pottery of LH I-LH IIIA date

octagonally hilted and straight flange hilted swords

Fig. 1.

Trade networks during the 16th-14th centuries BC, when a Nordic/Tumulus Culture network was connected to a Mycenean/ western Mediterranean network. Amber was the most valuable trade item from the Nordic zone. Mycenaean pottery is present in northern Italy in the Terramare settlements from LH IIIB onwards. Digital drawing by Richard Potter 


\section{K. Kristiansen \& P. Suchowska-Ducke CONNECTED HISTORIES 1500-1100 BC}

development and freelance commercial trade from political ties (Sherratt \& Sherratt 1991).

\section{Agents of the international Bronze Age networks}

During the Bronze Age, vast networks of communication thus connected the European continent with the eastern and western Mediterranean, transforming physical geography into social geographies. Social networks consisted of interpersonal relations and diplomatic alliances, established and maintained through the exchange of extraordinary objects. Increased connectivity fostered the emergence of political alliances, treaties, and the rule of guest-friendship, allowing the agents of social interaction to travel to distant places and acquire knowledge, both geographical and technological (Kristiansen \& Larsson 2005, particularly chap. 2). Based on archaeological and written sources it can be assumed that the main categories of people who travelled during the Bronze Age were traders/merchants and smiths/craftsmen, warriors and mercenaries, migrants, and diplomats (see Fig. 2 for a model of these agents of mobility and their institutions). Traders, smiths, and warriors in particular were at the heart of the economic system, as they fulfilled the most basic need of connected societies for access to non-local resources and skills. Through these long-distance journeys and irreversibly linked societies, knowledge, skills, and technologies (such as metal-working, architecture, and shipbuilding) were distributed (and locally adapted) across Europe and the eastern Mediterranean.

Ancient texts from the eastern Mediterranean present a very complex organisation of trade and exchange in the region, ranging from state-sponsored trading expeditions to private ventures conducted by stateless middlemen and wealthy merchants such as Sinaranu tamkaru of Ugarit (Astour 1972; Heltzer 1988; Monroe 2011). A most illustrative example of mercantile travel in the 'globalised' Bronze Age world is the Uluburun shipwreck (Bass 1991; Pulak 2001). The ship's cargo contained raw materials and finished goods from most parts of the known world, and its crew was fairly 'international', as indicated by their personal possessions and also by the tools they used (ie the sets of weights that possibly belonged to four

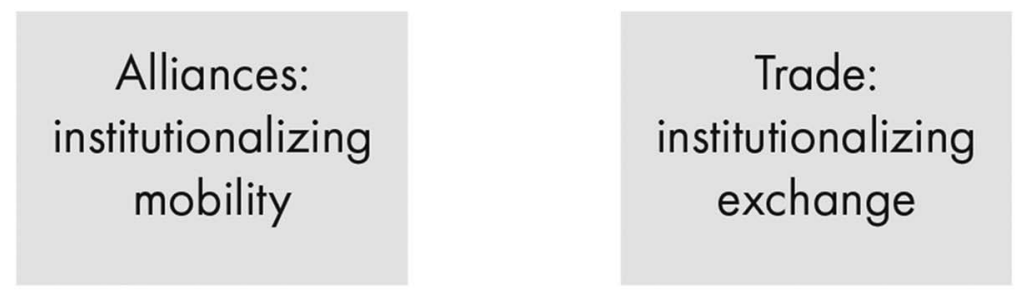

$$
\begin{gathered}
\text { Colonization: } \\
\text { institutionalizing } \\
\text { expansion }
\end{gathered}
$$
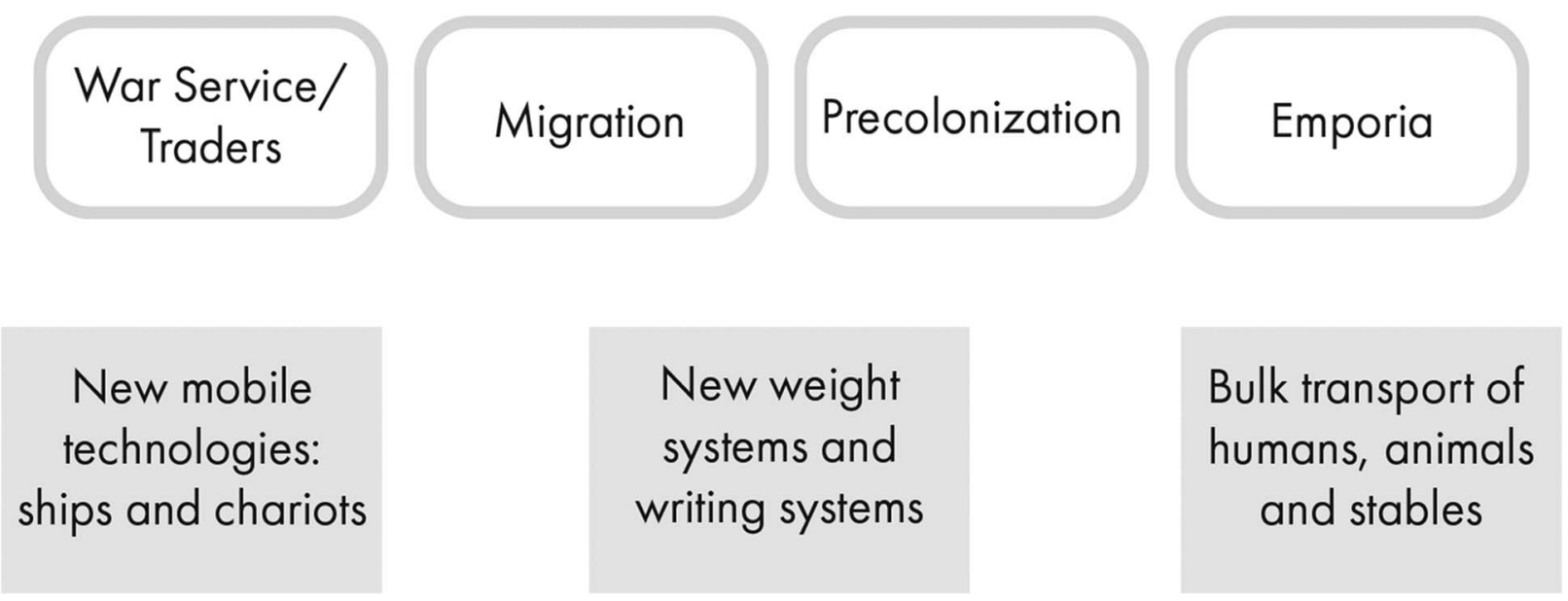

Fig. 2.

Model of the most common agents of mobility and their institutions during the Bronze Age. Digital drawing by Richard Potter 
merchants and tools used by smiths working on board, as well as weaponry that belonged to possibly three warriors). In the Late Bronze Age, traders were also diplomats that served as emissaries and messengers, as a letter sent to the Pharaoh confirms, in which the king of Alasiya asks: 'My brother, let my messengers go promptly and safely so that I may hear my brother's greetings. These men are my merchants. My brother, let them go safely and promptly' (Moran 1992, 112). There is no doubt that, in spite of constant competition, hostility, and military conflicts, all city-states were linked to each other within wide-ranging trading networks. Moreover, traders accompanied armies. Frequently, they even arrived in advance of armies and could be an important source of information. Caesar most famously acknowledges this important role of traders when he said that 'no one, except traders, goes there [to Britain] without good reason' (Gallic Wars, 4.20).

An interesting example of inter-regional integration and long-distance mobility is given by the Old Assyrian trading colonies that belonged to the city of Ashur and were located about $1200 \mathrm{~km}$ away from the latter, in central Anatolia (cf. Bryce 2002; Barjamovic et al. 2013). The most important of them was the karum at Kanesh (modern Kültepe), where more than 15,000 tablets have been found. It needs to be emphasised that it is only thanks to these written sources that it was possible to identify the merchant quarter as Assyrian, as all the houses and material culture recorded on the site were entirely Anatolian. Based on tablets from Kanesh and the royal inscription, Ashur's society can be depicted as complex in composition, and largely run by a powerful group of merchants who sent some of their male relatives to settle in one of the Anatolian colonies to direct and promote the family business. Kanesh's position in the centre of the important communication network allowed Ashur to benefit from the tin and textile trade.

Mercantile travels in the Mediterranean and Near East were hazardous. The Amarna letters refer to a number of incidents of traders being attacked and murdered (Bryce 2002, 89-90; Barjamovic et al. 2013). In one letter, the king of Babylon Burna-Buriyash II complains to Akhenaten that his merchants were murdered in Canaan by subjects of the pharaoh, and demands that the perpetrators be punished. The Hittite kings also tried to encourage the authorities of the districts located on the trading routes to put greater efforts into protecting travelling merchants against crime and to assume responsibility for the merchants' safety. When they failed, they were forced to pay substantial compensation to the traders themselves or to their families and business associates. A merchant could claim compensation for damage to his cargo or equipment as well, whether caused accidentally or through negligence. These efforts to create a legal framework for trade and to protect merchants, even if often unsuccessful, highlight the importance attached to their role in the network of international communication during the Late Bronze Age.

Trade in the Bronze Age Mediterranean Basin and Near East was ever expanding in scale, especially during the 15th-13th centuries BC, most notably in the many settlements with Mycenaean pottery. The intense crosscultural contacts in the region are attested to by the discovery of Aegean-made items in foreign contexts and eastern Mediterranean-style objects in the Aegean (Cline 2009; Hitchkock \& Maeir 2014; Suchowska-Ducke in press). The regular connectivity between Bronze Age communities meant that knowledge could be obtained about faraway places on a regular basis (Tartaron 2013). Traders were the new specialists who provided such knowledge and the organisational skills to connect distant places and their goods (Van Wijngaarden 2012). But warriors also became widely sought after as mercenaries in the eastern Mediterranean during the Late Bronze Age from the 15th century onwards, as is well attested in texts and on stelae, not least in Egypt (Morkot 2007). It explains how new sword types could spread rapidly from the Mediterranean to Scandinavia probably within a few years. Thus the combination of trade in metal and possibly in arms, as well as travelling warrior groups and their attached specialists, created an interconnected 'globalised' world without historical precedent.

\section{THE EMERGENCE OF MEDITERRANEAN/EUROPEAN TRADE NETWORKS 1600-1200 BC}

Taking into consideration the cited evidence for eastern Mediterranean colonisation and the organisation of trade and exchange in the region, it seems justified to ask whether Mycenaean items and settlements found in Sicily and southern Italy, and now also northern Italy, are indications of similar mercantile activity (see discussion by Blake 2008; Cazzella \& Recchia 2009; Vianello 2009 versus Jung 2005). A Mycenaean presence is most evident in the Thapsos settlement, already beginning during the 16th century BC (Militello 2004), and Mycenaean influence on the region increased in scale during the 13th and 12th centuries $\mathrm{BC}$, when 


\section{K. Kristiansen \& P. Suchowska-Ducke CONNECTED HISTORIES 1500-1100 BC}

Aegean pottery and Aegean (as well as Cypriot) types of metalwork were being produced in the central Mediterranean (Jones \& Vagnetti 1991). For instance, the archaeological finds from Scoglio del Tonno in southern Italy and Frattesina in the Po Valley are mixtures of local and Mycenaean pottery and figurines and Aegean, Italian, and Central European metal forms (such as violin-bow fibulae, Peschiera daggers, and winged axes), representing cultural diversity comparable to the port-oftrade of Ugarit. These sites can be seen as emporia that played an important role in the extensive trade network and places where Mycenaean traders and craftsmen were present. In addition, the casting mould of a so-called 'winged axe', a type common in temperate Europe that was found in the House of the Oil Merchant at Mycenae, is considered an indicator of the existence of itinerant craftsmen (Bietti Sestieri 1988). Sardinia was likely another important hub in this western Mediterranean trade network, although it's precise role is debated (Giardino 1992). According to recent results from lead isotope analyses of Nordic bronzes from Period II and III (1500-1150 BC) most copper came from Sardinia and/or the Iberian Peninsula during this period (Ling et al. 2014).

Mediterranean trade was well organised and diversified, allowing producers and distributors to cater for a wide range of consumer needs. It was also standardised on the level of commodities exchange, such as the trade in pottery, wine, and olive oil. For the transportation of large quantities of metal a distinctive type of Mediterranean oxhide ingot was used (cf. Sabatini in press). The wide circulation of these ingots, from the coast of the Mediterranean Sea all the way to the Black Sea and Central Europe clearly points out how strongly interconnected Bronze Age societies were. Commercial communication between the two regions is well illustrated by an oxhide ingot found in Tscherkovo in the Burgas district, which bears traces of an inscription in Cypriot-Minoan linear writing (Buchholz 1983; Suchowska 2009, with more examples). It is possible that temperate Europe was also directly linked to this international network of trade and exchange, as the four fragments of oxhide ingots found in Oberwilflingen in Baden-Wüttenberg in Germany, made of Cypriot copper and dated to the 14th/13th century BC, may indicate (Primas \& Pernicka 1998). Representations of various types of oxhide ingots have recently been identified in Scandinavian rock art (Ling \& Stos-Gale 2015), and are also found symbolically represented in European metalwork (Popa 2014).
In Figure 1 we have summarised the evidence of regional trade networks and their interactions during the 16 th-14th centuries BC. The connecting valuable was Baltic amber, which was exported from Jutland and the Baltic to southern Germany and the Aegean, where it was made into complex necklaces. Each region in this inter-regional network thus possessed something the other regions craved or needed. Wessex and southern England possessed tin (one of the few areas in Europe where it is found) which is needed for the production of bronze. South Scandinavia possessed amber - the tears of the Gods - which was regarded as divine and was especially sought after by the Mycenaeans, though we find it also in Syria and Egypt. From these locations Mesopotamian and Egyptian blue glass was exported via Mycenaean traders back to Denmark (Walton et al. 2009; Varberg et al. 2015). Copper was found in several regions, but it is characteristic that large-scale mining only took place in a few areas at any given time (O'Brien 2015). The Alps possessed rich sources, as did Sardinia and Cyprus. Sardinia/the Iberian Peninsula was perhaps the main deliverer of copper to Northern Europe during this period, and it explains the direct route taken by traders to southern Germany and further north to Denmark after 1500 BC, when southern England and Wessex lost some of their importance. Southern Germany was the new hub and the direct connection to Jutland and the amber route, as indicated on Figure 1. It lasted for 200 years, after which it was taken over by an eastern Central European/Balkan route.

During the Middle Bronze Age, 16th-13th centuries $\mathrm{BC}$, the entire European continent was thus integrated into a full Bronze Age economy. We shall therefore consider next how these European trade networks were organised and what the roles of warfare and warriors were in this context. But first a few words about the pan-European flange-hilted sword.

\section{A NEW WEAPONS TECHNOLOGY \& ASSOCIATED SOCIAL CHANGE}

Flange-hilted swords can be characterised as relatively long and heavy weapons with distinctive parallel-sided cutting edges and a thick cross section. ${ }^{1}$ Flange-hilted swords are functional warrior swords, and from their emergence around $1500 \mathrm{BC}$ onwards they often display traces of use and damage from actual combat (Foltiny 1964; Kristiansen 1984; Uckelmann \& Mödlinger 2011). On Figure 3 we compare the degree of 


\section{Use wear/resharpening of Central European and Thy flange hilted swords}

60

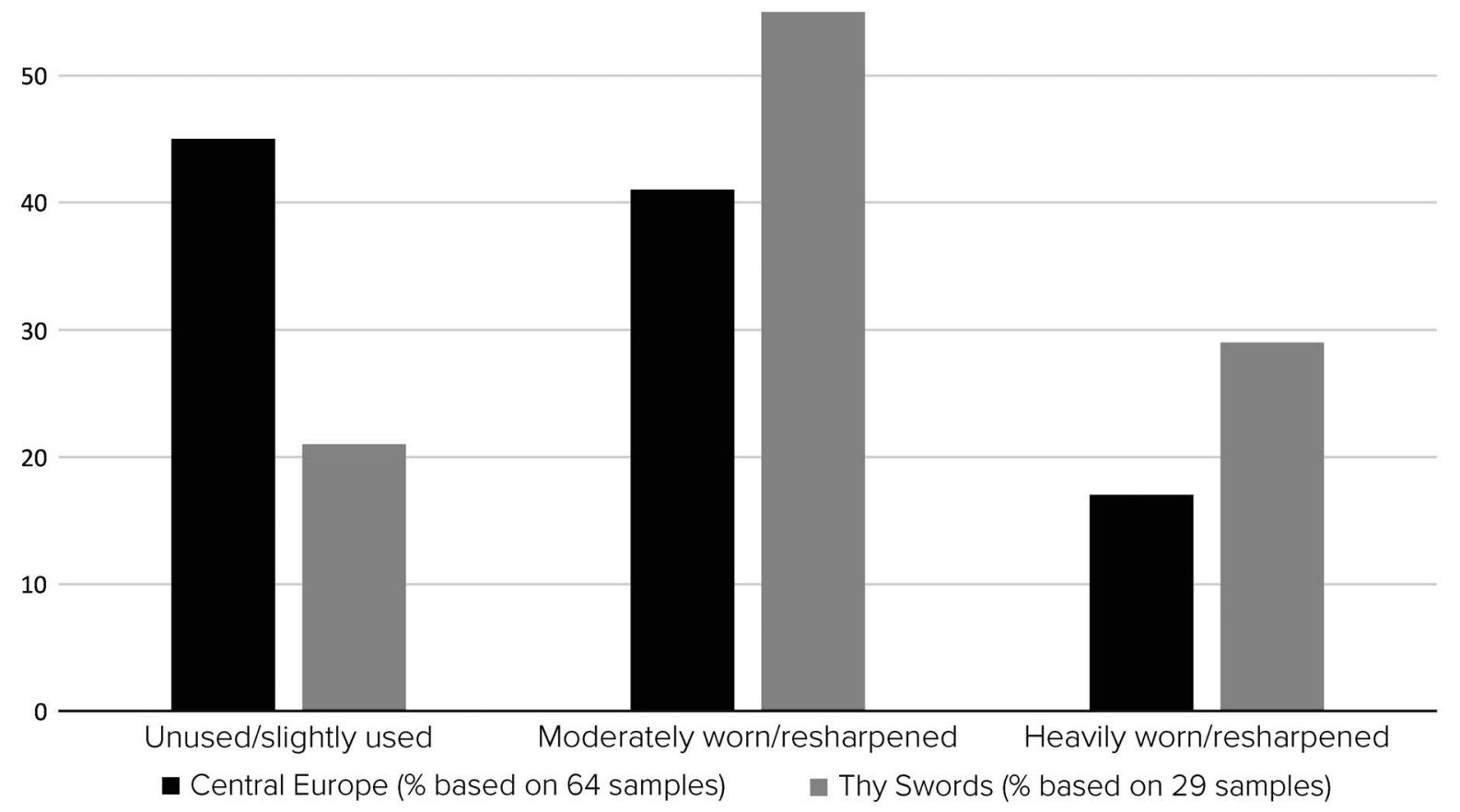

Fig. 3.

A study of re-sharpening of a group of Central European Swords of Type I and II (1500-1150 BC) (mainly from the National Museum in Budapest and some provincial museums in Hungary) compared to a small sample from north-west Jutland in Denmark of the same period, but with more Type II swords. It shows that swords were used in combat, and that they were in use slightly longer in Denmark/Thy than in Central Europe. Importantly, the swords had the same function as a combat weapon in both regions. Digital drawing by Richard Potter

re-sharpening of the blade due to combat in Central Europe and north-western Jutland during the period 1500-1150 BC. We merge the early and late types Naue I and II to achieve a representative sample, as previous studies showed no significant difference between them (Kristiansen 1984, figs 6 \& 7). The analysis shows that they were used in combat, as they always have razor sharp blades, even the unused pieces. It also shows that they were apparently more heavily re-sharpened in Jutland than in Central Europe. Sometimes they have small notches on the blade from combat that sharpening could not eliminate.

Broken rivet holes and broken hilts also testify to their use in heavy fighting. The pattern of re-sharpening the majority of moderately used blades demonstrates their use over longer periods of time, and expectedly there were more unused or slightly used swords in Central Europe closer to metal supplies. When blades become heavily worn they lose much of their functionality, as the blade becomes thinner and sometimes much shorter due to the breaking of the tip. But such swords also indicate that metal was not available to warriors at all times or simply could not always be afforded. The solid construction of flange-hilted swords makes them robust and resistant against bending. They were also longer and heavier than other swords of their era (around $60 \mathrm{~cm}$ blade length), and their balance points were located significantly further away from the hilt allowing more kinetic energy to be transferred to the tip of the blade 


\section{K. Kristiansen \& P. Suchowska-Ducke CONNECTED HISTORIES 1500-1100 BC}

and thus providing better armour penetrating power (Kristiansen 2002; Jung \& Mehofer 2009). For these reasons, it has been argued that the appearance of flange-hilted swords, equally suitable for thrusting and cutting and for close hand-to-hand combat, marks a significant change in the fighting techniques among Late Bronze Age societies (Drews 1993). However, another significant change took place around 1350/1300 BC when the blade became wider and heavier, therefore more suitable for slashing than thrusting. This is exemplified by the Naue II sword, which became the preferred warrior sword in the coming centuries.

As mentioned, flange-hilted swords were highly functional weapons, versatile and efficient in combat but also relatively easy to manufacture. Therefore, they quickly became the weapon of choice for a class of professional warriors that likely sought profit as raiders and mercenaries (Kristiansen \& Larsson 2007). These highly mobile warriors can be assumed to have been a driving force behind the rapid spread of this weapons technology, and there is no doubt that its international distribution from Northern Europe to the Aegean is truly remarkable. Most significantly, these professional warriors must have been at least partially responsible for many profound cultural transformations of their societies of origin by bringing back from their voyages new impressions, ideas, innovations, and material wealth. These assumptions are supported by many finds of Greek armour such as greaves, corslets, and helmets, as well as Mycenaean swords and rapiers, which have been found in the Balkans and in Central Europe during the Late Bronze Age (cf. Harding 1984; Bouzek 1985; Suchowska-Ducke in press). These finds may be interpreted as evidence of warriors returning home. This warrior heritage is perhaps most impressively preserved in the numerous graves in Denmark and northern Germany, many of which contained flange-hilted swords with signs of use-wear that clearly indicate that they were used in real combat (Fig. 3), but also with full-hilted swords that were symbols of social status (Kristiansen 1984; 2002).

We shall now look more closely at the role of flange-hilted warrior swords versus other types of full-hilted swords during the period 1500-1100 BC.

\section{WARRIORS AND TRADERS OF THE FLANGE-HILTED SWORD 1500-1300 BC}

Two distinct sword types connect southern Central Europe and South Scandinavia during the 15th-14th centuries BC: the full-hilted sword with octagonal hilt, and the flange-hilted sword. These were supposedly linked to two different types of travel: trade and mercenary, but with obvious overlaps and modes of collaboration between them (Fig. 4).

We shall now explore how new European trade networks were established that were able to connect the European hinterlands, which provided such essential goods as amber, tin, warriors, and perhaps slaves (see Briggs Nash 2006 for the earliest Etruscan evidence on depictions of blonde northerners) to the Bronze Age palace economies in the Near East and the eastern Mediterranean. This trade was supported by central meeting places such as Monkedonja in Istria (Krause 2006/7; Hänsel 2007), the Terramare Culture in the Po valley (Vianello 2005), and the large fortified settlement at Bernstorf in southern Germany (Bähr et al. 2012). They reflect the opening of a direct trade link to South Scandinavia to obtain amber directly from the source rather than via Wessex or the Carpathian tell cultures, which had previously been the case. This commercial shortcut directly to the source marks the start of a most remarkable flourishing of a Nordic Bronze Age culture, which suddenly became incredibly rich in copper, tin, and even gold. During the next centuries South Scandinavia produced and deposited more elaborate bronzes in graves and hoards than any other region in Europe. Baltic amber likewise ended up in rich graves in southern Central Europe, Italy, and in Mycenaean graves (Czebreszuk 2011; 2013), as well as in the Levant and Syria (Mukherjee et al. 2008). If we consider the rate of exchange between amber, gold, and copper, the economic gain for South Scandinavia by taking charge of this trade becomes easier to understand. According to textual evidence (Morkot 2007):

- gold, silver, and copper in the New Kingdom was calculated as 1:2:200; and

- in Ugarit around $1200 \mathrm{BC}$ as 1:2:400.

If we, as a conservative estimate, replace gold with amber as in Roman times, we can calculate its value in the Mediterranean: $2 \mathrm{~kg}$ amber $=400 \mathrm{~kg}$ copper. An experienced amber collector can, after the days following a storm, collect up to $2 \mathrm{~kg}$ amber on the west coast of Jutland with a bit of luck (Bech in press). Huge quantities of amber were thus in all probability exported south every year from Jutland. This explains the incredible wealth after $1500 \mathrm{BC}$ in bronze and gold in South Scandinavia, even if we subtract profits for middlemen on the way. Copper imported to South Scandinavia had its origin in the western 


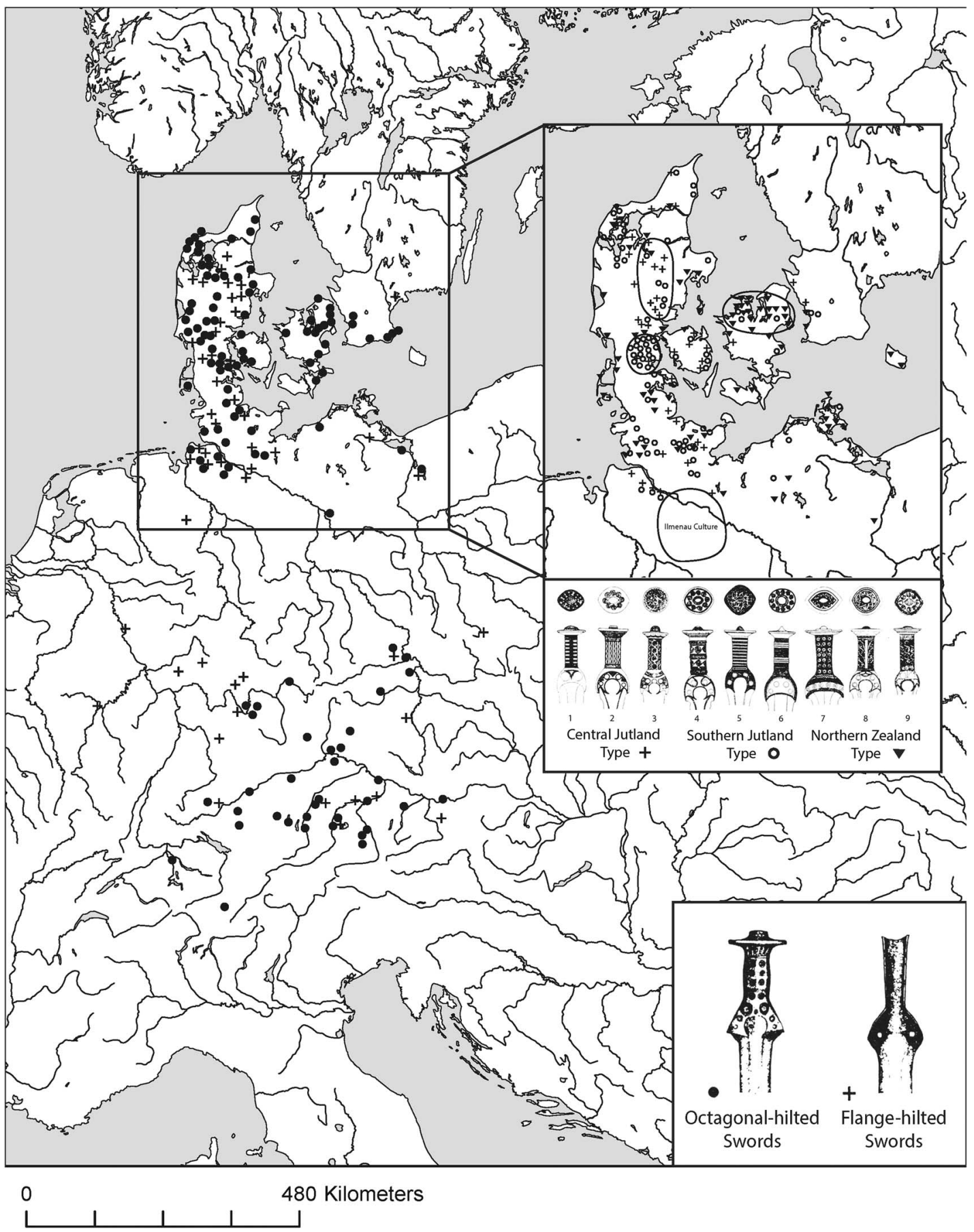

Fig. 4.

Distribution of foreign swords, flange-hilted and octagonal-hilted, connecting southern Germany and Denmark, versus the distribution of Nordic full-hilted swords. Digital drawing by Richard Potter 


\section{K. Kristiansen \& P. Suchowska-Ducke CONNECTED HISTORIES 1500-1100 BC}

Mediterranean according to lead isotope analysis (Ling et al. 2014), and mostly consisted of one dominant copper type (Liversage \& Northover 1998). It suggests some form of trade monopoly, or at least the dominance of one or a few mining areas.

It is therefore not surprising that Europe and the Aegean during the 15th-14th centuries BC shared the use of similar efficient warrior swords of the flange-hilted type, as well as select elements of shared lifestyle, such as campstools. Linked to this are also tools for body care, such as razors and tweezers. This whole Mycenaean package, including spiral decoration, was most directly adopted in South Scandinavia after $1500 \mathrm{BC}$, creating a specific and selective Nordic variety of Mycenaean high culture that was not adopted in the intermediate region (Kaul 2013). This could hardly have come about without intense communication and practice by travelling warriors or mercenaries. Swords come in different types and have different fighting styles (Kristiansen 2002; Molloy 2010). Therefore they are not easily adapted: they are part of a system of warfare and skills that demand long-term training. Furthermore they demand changes in social organisation in order to sustain the new role of warriors. It therefore seems likely that warriors were at the same time also traders, or they accompanied traders to protect them. We may therefore accept that the shared use of sword types among Scandinavia, Central Europe, and the Aegean during this period would also lead to similarities in the social institutions linked to warriors. This seems indeed to be the case: the dual organisation of leadership between a Wanax and a Lawagetas in the Mycenaean realm is replicated in the Nordic realm, which also copied Mycenaean material culture closely (Kristiansen \& Larsson 2005, chaps 5.4 \& 6.5). However, we should also be open to the possibility that this dual organization was part of a shared Indo-European Bronze Age tradition (Kristiansen 2013b).

A case in point in the Nordic Early Bronze Age is the constitution of Wanax type ritual chiefs characterised by a certain recurring set of ritual objects and symbols, and Lawagetas type warrior chiefs characterised by a different set of recurring objects without ritual references. The ritual chief is distinguished by a special package of objects, linked to shared aesthetics and lifestyle elements from the Aegean to Scandinavia (Kaul 2013; Ruiz-Galvez Priego \& Galán 2013), such as campstools and drinking vessels with sun symbols at the bottom - the sun would rise when lifting the cup that contained mead. Razors and tweezers are also often linked to this group of ritual chiefs, which share the exclusive use of spiral decoration, the symbol of the sun cult and of Nordic identity. The sword would often be full-hilted and used for parade rather than warfare, rarely sharp and rarely damaged (see Kristiansen 1984 for an empirical documentation of the use of different sword types).

The warrior chief, on the contrary, would have a highly functional, undecorated flange-hilted sword of an international type distributed from southern Central Europe and the Aegean to Scandinavia. It was the sword of the professional warrior, always sharp edged and often re-sharpened from damage in combat (Kristiansen 1984). The warrior chiefs would rarely have any of the ritualised symbolic objects of ritual chiefs, which suggest that they were denied access to this office. They shared with ritual chiefs burials in an oak coffin under a barrow, and a chiefly dress consisting of cape and round cap, both costly and socially distinctive of the free man of chiefly lineage. They also shared burials in barrows, which correspond ritually to 'free men' who owned cattle and farms, in opposition to those who had smaller houses without stalling for cattle (Kristiansen 2013a; also Bunnefeld 2014).

Finally, we have a third group with octagonal-hilted swords of southern German origin, but also produced in Denmark by migrant smiths, as they employed a specific casting method different from that of the Nordic smiths (von Quillfeldt 1995; Bunnefeld \& Schwenzer 2011). Like the warriors they do not have any of the paraphernalia of the ritual chiefs, and they share the same international distribution as the flange-hilted sword. They represent a group of people who might be linked to trade and smithing (Kristiansen \& Larsson 2005, fig. 107). These three groups are represented by several hundred burials, and they serve as a prime example of Ian Hodder's dictum that material culture is meaningfully constituted. In a rather straightforward way they demonstrate that different sword types in the Bronze Age were meaningfully linked to different social and ritual institutions and social identities.

Thus, the two institutions of ritual chiefs and warrior chiefs/traders have radically different distributions, and this informs us about their different roles in the reproduction of a complex set of regional and inter-regional identities, some of which formed a 
collective ethnicity and some of which formed a political identity. The ritual chiefs maintained the ritual and cosmological order of society, defined by a symbolic package of objects and the spiral decoration. The spiral signalled Nordic identity, a shared religious cosmology, and probably also a shared cosmological origin, in this case Mycenaean. These chiefs were in charge of rituals, and controlled the huge corpus of religious and legal texts vital to the correct performance of rituals and the maintenance of order. Therefore Nordic ritual chiefs never, or rarely, moved outside the cultural boundaries of this 'ethnic' identity - defined as a shared symbolic world of cosmological origin (Jones 1997). However, the Nordic identity displayed in the spiral style of chiefly objects refers back to a distant Mycenaean template of high culture that was not shared with other Central European Bronze Age groups.

The warrior chiefs, on the contrary, were culturally defined as 'foreign,' which allowed them to travel and maintain political connections outside the symbolically defined ethnic world of Nordic Culture. Therefore they maintained and carried the inter-regional networks that constituted the flow of bronze and of foreign relations, supported by confederacies. They were part of a Central European/Northern European international network, with a shared material culture of Central European origin. We should thus envisage regular and direct long-distance trade expeditions between southern Germany and Jutland/Denmark during this period. Denmark and southern Germany were also the wealthiest regions in terms of grave goods, perhaps as a result of trade (Endrighkeit 2014; Müller 2015).

Ethno-historical evidence of warrior cultures supports such an interpretation of warriors and traders on the move. Warriors often formed special group identities (sodalities) that linked them in a spatial network defined by rules of special behaviour and etiquette. This could be employed both for recruiting war bands and for travelling to more distant chiefs to earn fame and foreign prestige goods, as evidenced in Africa among the Maasai, among the Japanese Samurai, and is a recurring feature in the literature on warriors and warfare in Indo-European literature (Otto et al. 2006; Vandkilde 2006; Kristiansen 2014). However, we must assume that other groups of people could travel or were even being traded as labour/slaves. Daphne Briggs-Nash's (2007) essay on travellers of the Early Iron Age also has bearing upon the Bronze Age.
We have demonstrated that institutions existed that took care of separate needs that were vital to Bronze Age societies: the internal maintenance of a shared cultural and cosmological world, and the external maintenance of political and commercial relations. Women achieved new social and economic status by being central to forging marriage alliances, and thus keeping the system open (Kristiansen \& Larsson 2005, chapter 5). This is evidenced by the recent analysis of the Egtved burial of an 18 year old woman (Frei et al. 2015). She travelled twice during her last two years between southern Germany and Jutland, and the additional little 5 year old child in the coffin, cremated, also came from southern Germany. It indicates the highly organised, directed nature of trade and travels between the southern German and Danish chiefly centres (Müller 2015).

Returning to the question of personhood and social identity, the sheer number of sword burials and the regularity they display in burial rituals and burial goods suggest that we are dealing with well defined, bounded institutions and social identities. In southern Germany these networks were joined by a western Mediterranean commercial network originating in the Mycenaean world as evidenced in Figure 1.

The archaeological finds fit nicely with numerous examples of both direct imports and indirect imitations of Minoan/Mycenaean objects and styles in the Nordic realm during the period 1450-1300 BC such as campstools and specific forms of spiral decoration that emulated Mycenaean prototypes (Kristiansen \& Larsson 2005; Krause 2006/7). Baltic/ Danish amber was the highly valued, mythical material behind these enterprises, which began during the Shaft Grave period (Maran 2004; Hughes-Brock 2005; Vandkilde 2013b) but became more regular and systematic with the opening of the direct trade link to Denmark via southern Germany; this is when amber became a regular feature in Mycenaean graves (Czebreszuk 2011; 2013). Warriors and traders moved on a regular basis between South Scandinavia, southern Germany, and probably even further. The Terramare settlement of northern Italy provided one such bridgehead or hub. Here we find both amber beads and also other evidence of northern connections in sword types and pottery (Cupito 2006, figs 37-8 \& 65; Aner et al. 2011, no. 9852, a Boiu sword in northern Germany, plus other southern items, nos 9853 and $9855 \mathrm{~A})$. Figure 1 illustrates the extent, and some of the content, of these networks/confederacies, 


\section{K. Kristiansen \& P. Suchowska-Ducke CONNECTED HISTORIES 1500-1100 BC}

which were kept together by treaties/political alliances between the chiefdoms, or rather kingdoms along the route, which in turn provided logistics and support for the traders. Dynastic marriages between chiefdoms/kingdoms along the route have long been demonstrated archaeologically (Jockenhövel 1991; Kristiansen \& Larsson 2005, fig. 107; Mordant et al. 2007). Such marriages provided political security for travelling warriors and traders, and although local warfare always contained a risk to the system, the benefits of maintaining stable alliances prevailed.

\section{WARRIORS \& TRADERS OF THE FLANGE-HILTED SWORD 1300-1150 BC}

This well-oiled network collapsed during the transition to the 13th century BC and was replaced by an East-Central European network of the Sprockhoff type II/Naue II flange-hilted sword (see Figs 5-6 for chronology and find contexts). The earlier Sprockhoff type I/Naue I sword had a narrower blade and could be used for both slashing and thrusting. The Naue II is a warrior sword more suitable for man-to-man combat where slashing dominates. Though it could also be used for thrusting, its wider and heavier blade made it more efficient for combat dominated by slashing, which eventually took place on horseback, as indicated by the cemetery of Neckarsulm. Emerging strontium isotope analysis, for example from Neckarsulm in southern Germany around 1300 BC, provides evidence that warriors could be hired by foreign chiefdoms. It is a male cemetery of 51 individuals, where one third were non-locals. However, before they died they shared the same healthy diet and were above average height. They were therefore most likely part of a chiefly retinue, and three sword graves distinguished the chiefly commanders. The skeletons also showed signs of riding, which may have been introduced by the Urnfield period (Wahl \& Price 2013).

Given the efficient design of the flange-hilted swords and the sheer intensity of warfare as a form of social interaction, it is hardly surprising that this type of weapon spread fast and over vast areas during the Late Bronze Age (cf. Suchowska-Ducke 2015). Hundreds of these swords have been found in Central and Northern Europe and in the Balkans, dozens in Southern and Western Europe and in the Aegean; several examples of Naue II swords are also known from Cyprus and eastern parts of Europe (Figs 5 and 6). The majority of flange-hilted swords have been found in graves (Scandinavia, northern Germany, and Greece) and in hoards (Carpathian Basin and Western Europe). Many Naue II swords were accompanied by a special package of objects that characterizes travelling warriors or mercenaries, such as other types of weaponry and tools, drinking vessels, and toiletries (razors, tweezers, combs, and mirrors), and also by such unique items as parts of armour and campstools (Deger-Jalkotzy 2006). The following are some examples of the often strikingly rich assemblages in which Naue II swords were embedded.

Particularly rich in finds are the hoards from Central Europe and the Balkans (Fig. 6). For instance, the hoard from Şpălnaca in Romania (dated to $\mathrm{Br} \mathrm{D} /$ HaA1) yielded 23 examples of flange-hilted swords, along with 24 other types of swords and fragments, parts of helmet, daggers, spearheads, axes, chisels, awls, fragments of a saw and hammer, sickles, a knife, a razor, fish hooks, belt fragments, pins, fibulae, an armlet, a neck collar, a necklace, several discs, beads of different materials, parts of horse harness, a metal vessel, as well as a tin scrap (Bader 1991, 89-90, 92, 95, 98). The Romanian hoard from Uioara de Sus (dated to $\mathrm{Br} \mathrm{D} / \mathrm{HaA} 1$ ) consisted of 15 Naue II swords, all items mentioned above, and additionally fragments of a diadem and a corselet, spirals, rings, and parts of a wheel (Bader 1991, 88-90, 96). In the Central European grave of Čaka in Slovakia (dated to $\mathrm{Br}$ D/HaA1) two flange hilted swords, the fragment of a corselet, two spearheads, a razor, an axe, two chisels, a pin, and fibulae have been found (Novák 1975, 20). In the Hungarian burials in Csabrendek and Mosonszolnok (both dated to $\mathrm{Br} \mathrm{C} 2 / \mathrm{D}$ ), Naue II swords were accompanied by, respectively: two spearheads, a decorated belt fragment, and a pin and armlet; in the other burial was a dagger, spearhead, armlet, pin, as well as two violin fibulae (Kemenczei 1988, 59).

Similar warrior-like packages of objects can be seen in graves from the northern and southern parts of the European continent. For example, in a grave dated to Period III from Elsted in Thy, northwestern Jutland (Fig. 7 shows the barrows), a flange-hilted sword was found along with a knife, a razor, tweezers, and two buttons (Aner et al. 2001, no. 5002). Several uniquely equipped burials are also known from Germany. In Goldenbow (Period III) a flange-hilted sword was accompanied by a knife, spiral fibulae, a pin, an armlet, two rings, and a campstool (Wüstemann 2004, 36), for which Mediterranean links are postulated 


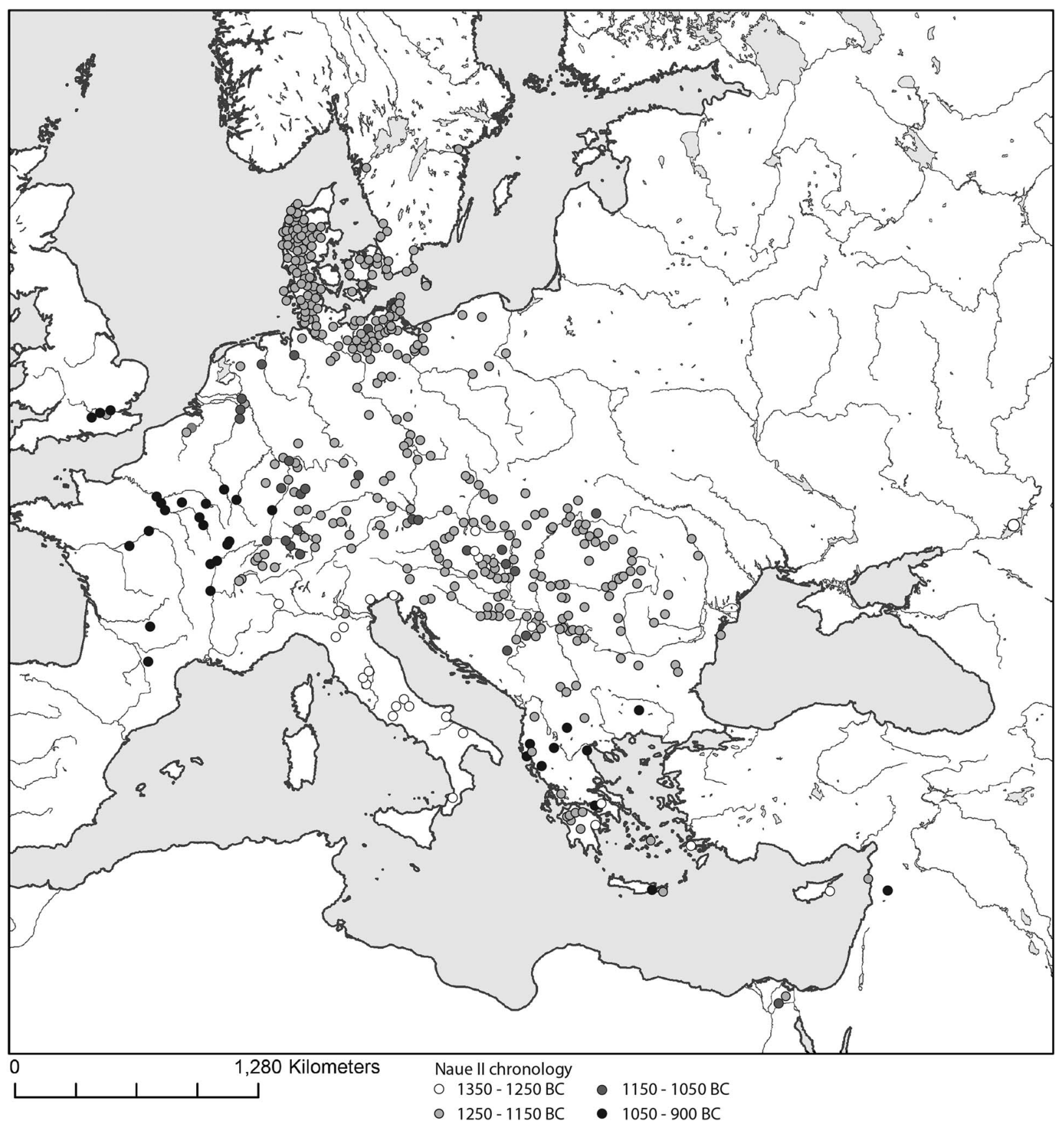

Fig. 5.

Approximate chronological classifications of Naue II finds. Digital drawing by Richard Potter

(Werner 1987). The burial from Weitgendorf (also from Period III) contained a Naue II sword, knives, a spearhead, a razor with a horse handle, and an amber bead (Wüstemann 2004, 39-40). In a grave from Wollmesheim (dated to HaA1/A2), along with a Naue
II sword, shield fragments (74 rivets), pins, fibulae, rings, a knife, an axe, a bracelet, spiral ornaments, hematite and nephrite beads, and a metal vessel have been found (Schauer 1971, 168-9). In Mycenaean Greece, in a tomb from Portes-Kephalovryso (dated to 


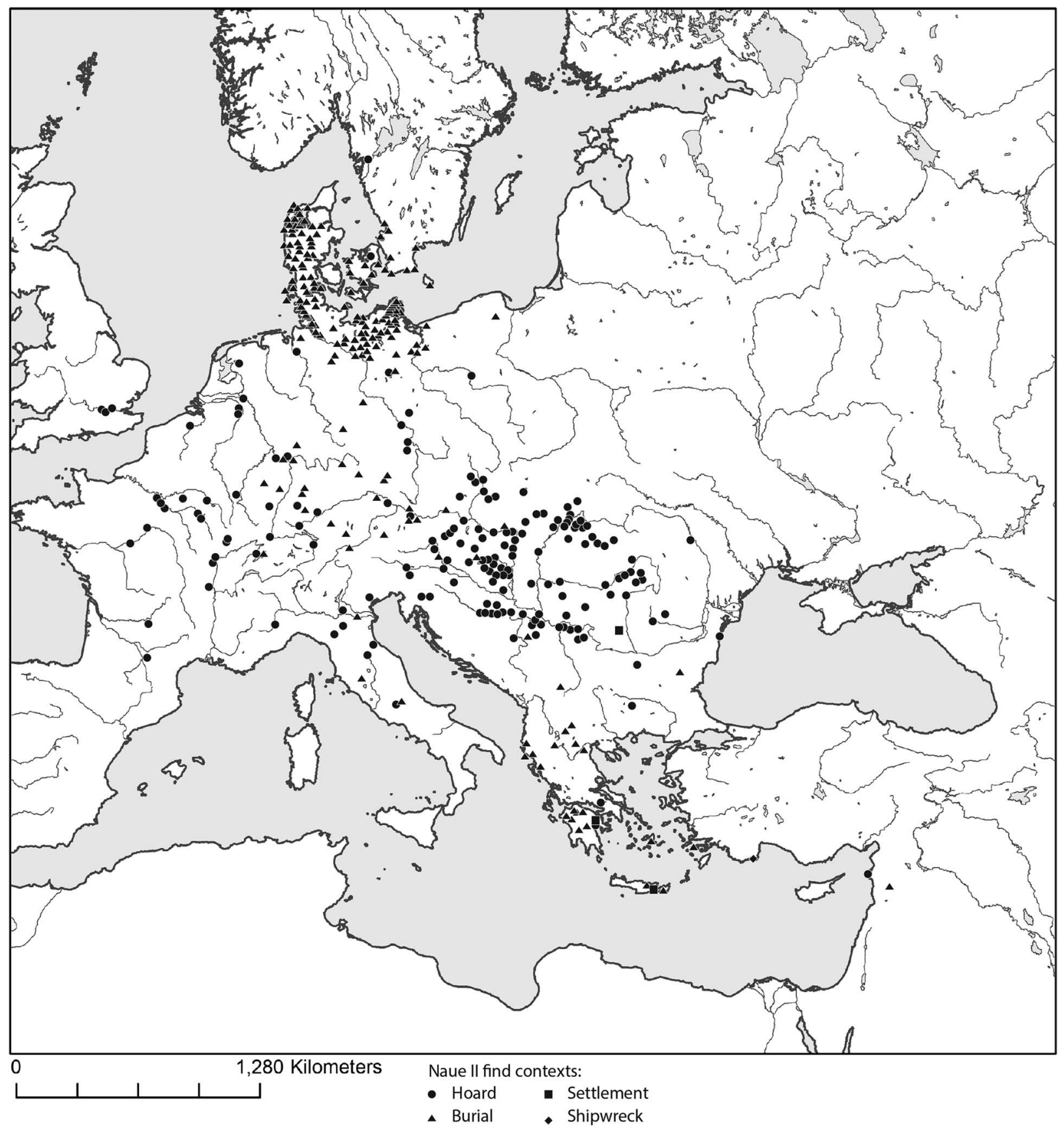

Fig. 6.

Contexts of Naue II finds. Digital drawing by Richard Potter

LH III C), a Naue II sword was found along with greaves, a spear, a knife, and a tiara-like helmet (Eder 2003, 40).

The evidence of such rich graves with Naue II swords stand in some contrast to the type I swords, which were rarely so well equipped. In Denmark it was the Nordic full-hilted sword that had the privilege of being accompanied by rich equipment, and this tradition continued during Period III. By Period III graves with flange-hilted swords also boasted similar equipment, as 


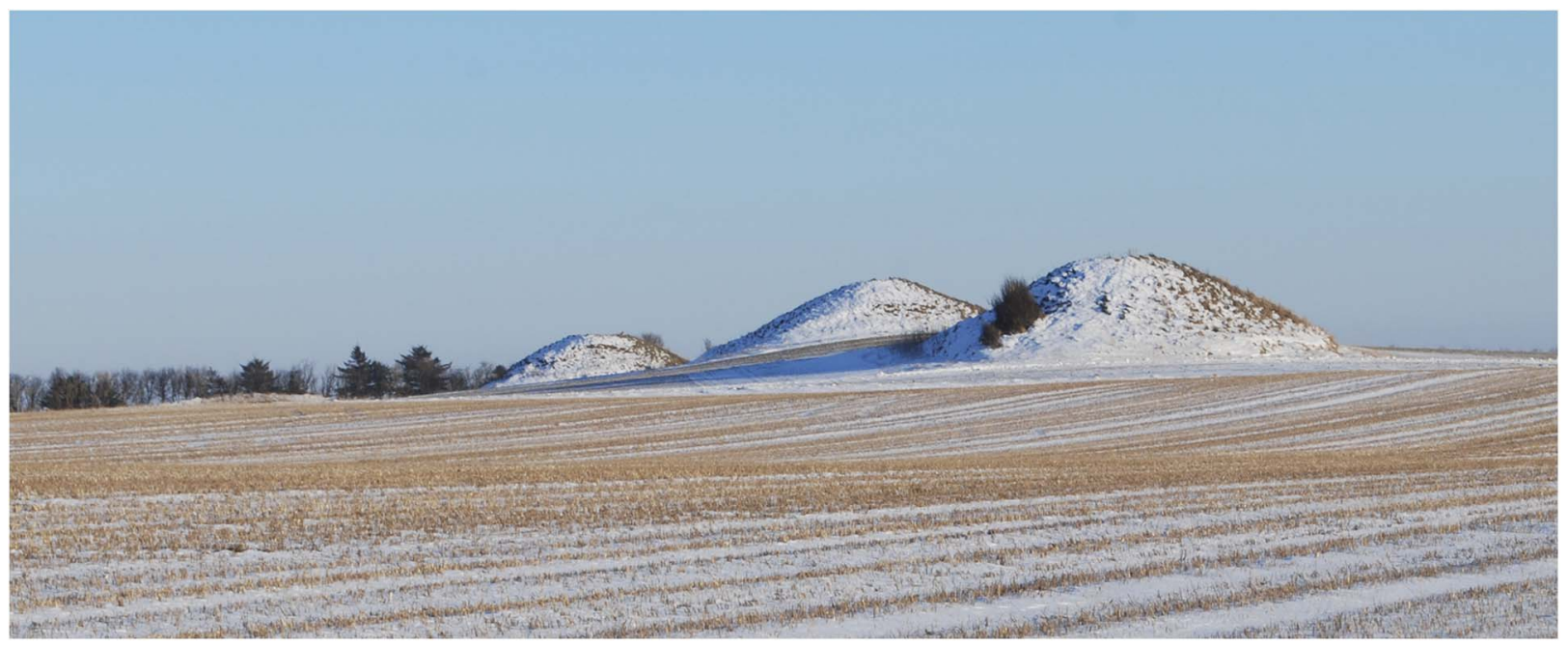

Fig. 7.

Burial mounds from Eldsted in Thy, Denmark. Photo by Jens Henrik Bech, Thisted Museum

demonstrated above. It suggests that Period III was a turbulent time where traditional warriors and mercenaries could rise to the highest chiefly positions, perhaps as part of social upheaval, or perhaps because warfare and warriors now allowed war leaders to take over chiefly leadership. We see this new trend from Achaea in Greece to the Nordic realm. Suddenly flange-hilted warrior swords of Naue II type appear in rich graves with local prestige goods. All evidence linked to the expansion of the Naue II sword thus points to disruption and violence along the way. How can this be substantiated archaeologically, and what was the scale of the violent events accompanying Naue II swords?

Already during Period III from 1350/1300 to $1150 /$ $1100 \mathrm{BC}$ we see that full-hilted swords are more often used in combat, just as some warrior burials in this period may contain the symbolic paraphernalia of ritual chiefs: razors and tweezers. The warriors are making claims to positions previously not open to them. The stable conditions of the 'golden' Period II had come to an end after 150-200 years of wealth expansion and consolidation of power for the ruling chiefly elites. However, during Period III, 1300-1150 BC, a dramatic change took place in the supplies of bronze, probably during the 13th century BC (HaA1). The old network with southern Germany, which had secured a steady flow of metal for amber during most of the 15th and 14th centuries BC and provided opportunities for warriors and traders to travel both ways (Fig. 4), was cut off due to warfare linked to social and religious reformation throughout eastern
Central Europe. The archaeological evidence for this is twofold: the successor of the octagonal-hilted swords, the Riegsee full-hilted sword, never reached Denmark, but we suddenly find a group of Riegsee swords in Slovakia, the new hub for contacts to the north (Fig. 8). We may interpret this as an attempt to forge new political alliances, but perhaps it is also a result of new east/west hostilities on a regional scale. At the same time we see a geographical expansion of hoarding (Fig. 8), which was an old ritual tradition in the Carpathians, but now also occurs in central Germany and former Yugoslavia, suggesting either the intrusion of new people from the Carpathian Basin and/or new hostilities. In the Nordic zone, and in the area of the former Tumulus Culture as well as in the Aegean, warrior burials continued and suggest the continuation of old social and ritual traditions (Sperber 1999). In southern Germany one of the central hubs of trade, Bernstorff, was heavily fortified around 1340 BC and shortly after burned down and deserted. Bernstorff is the largest fortified settlement in southern Germany/western Central Europe with a size of 14 ha. Its huge fortifications were constructed in the Middle Bronze Age (middle of the 14th century BC), when the power balance between eastern and western Central Europe was changing, and shortly after it was devastated and burned down along $1.6 \mathrm{~km}$ of its length (Bähr et al. 2012). We will probably never know who the enemies were, but we might suspect them to be outsiders, because at the same time we find evidence of major upheavals in eastern Central Europe. 
K. Kristiansen \& P. Suchowska-Ducke CONNECTED HISTORIES 1500-1100 BC

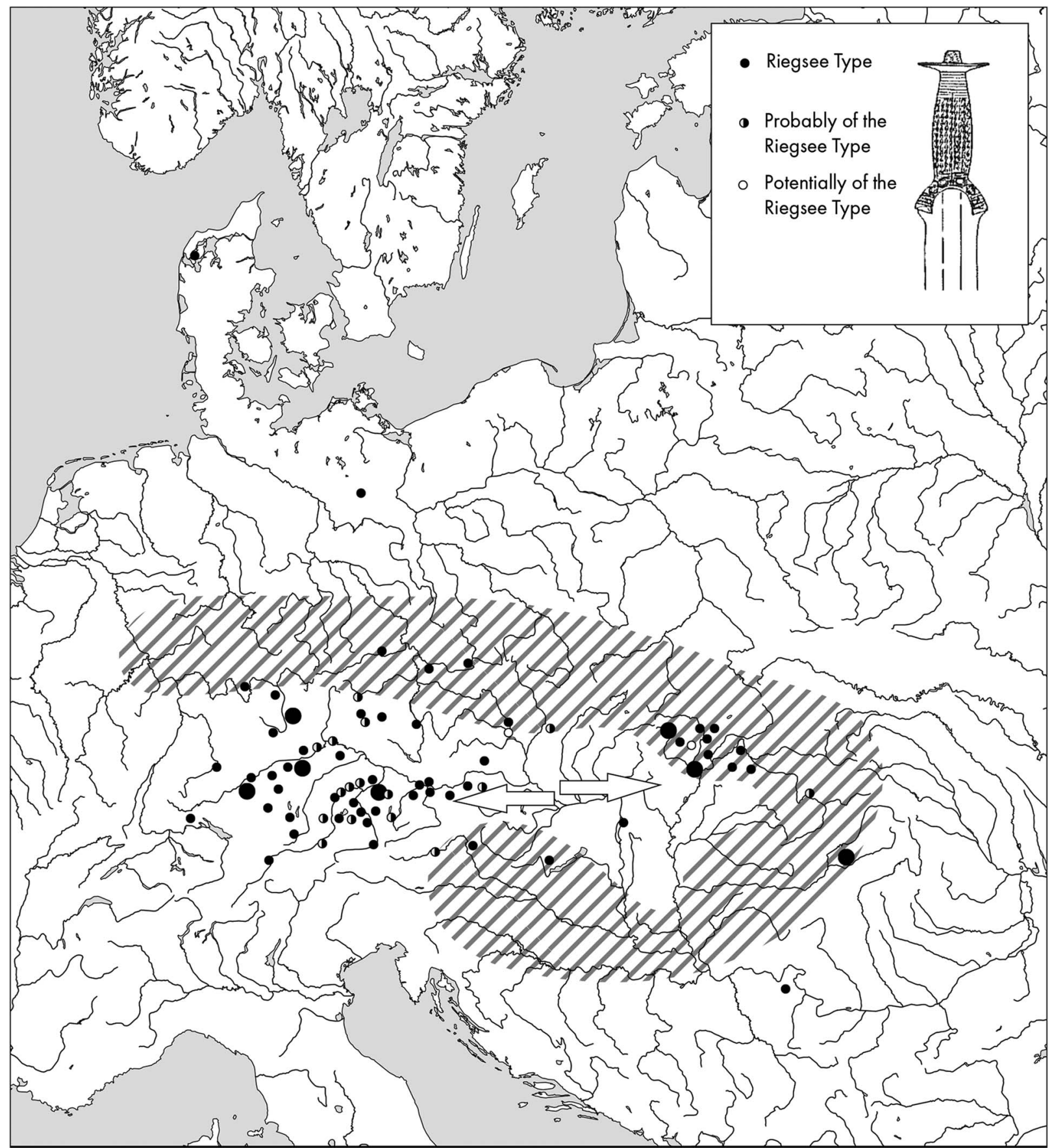

0

480 Kilometers

Fig. 8.

The distribution of the Riegsee type full-hilted sword, which replaced the octagonal-hilted sword, plus the distribution of areas (hatched) dominated by hoard depositions (based on von Quillfeldt 1995, Tafel 118; Hansen 1991; 1994, Beilage 1). The trade link to the Nordic zone has collapsed. Digital drawing by Richard Potter 
In the Carpathians and Transylvania huge metal hoards containing up to a ton of objects are deposited, testifying to the collapse of the traditional metal distribution system, and in the west in southern Germany, full-hilted swords of 'Riegsee' and 'Dreiwulstschwerter' type are becoming more and more worn on the hilt, as they had to be kept in circulation longer (Figs 9 and 10). From Riegsee to Dreiwulstschwerter the number of heavily worn swords increases to nearly $50 \%$, which, however, corresponds to similar figures in Denmark ${ }^{2}$ (Kristiansen 1978, fig. 3). This figure should be compared to the previous period when there was a balance of unused, moderately and heavily worn swords (Fig. 11; Kristiansen 1978, fig. 2). This increase in circulation time is a sure sign of declining metal supplies due to a rather long-lasting breakdown of regular trade. In addition these later types of full-hilted Central European swords rarely came to Northern Europe. They testify to a new east-west Central European network, with a high degree of stylistic and formal homogeneity among swords, suggesting that either few workshops existed, or imitation was common (Stockhammer 2004, chap. 6). It was in the Nordic realm, however, that the unstable supply of metal during the 13th century BC was felt most strongly: here a whole generation of full-hilted Nordic swords had to be kept in circulation for a prolonged period of time. As a result their hilts were completely worn down, and furthermore the bronze was worn away in several places laying bare the inner clay core of the casting. This phenomenon can be observed throughout South Scandinavia and northern Germany during Montelius Period III, and it is well-documented in the Aner and Kersten volumes I-XX in drawings (eg, Aner \& Kersten 2001; 2011). In Figure 12 we show a photo of such a sword from Thy. Full-hilted Nordic swords were finally deposited in burials towards the end of Period III during the 12th century BC when supplies were becoming stable again, now through political alliances with the Carpathian region.

These dramatic historical events tended to undermine the authority of ritual chiefs in the Nordic zone, which was linked to control over rituals and metal that was now becoming sparse, whereas warriors might benefit from taking part in raids and returning with riches from booty. In this way they could mobilise alternative wealth from raid and plunder, whether at home or as mercenaries in Central Europe or the Aegean where the flange-hilted sword testifies to the appearance of warriors from the north, mainly from Italy but also from Central Europe (Clausing 2003, Abb. 2; Jung \& Mehofer 2013).
As return payment and booty they would bring new body armour to Central Europe (Goetze 1984; Clausing 2003, Abb. 4). Thus, after the deposition of the last generation of full-hilted Nordic swords towards the end of Period III, we see a major reorganisation of burial rituals. From this point urn burials become the norm, and large objects such as swords are no longer deposited, except in rare circumstances. The construction of thousands of barrows made of grass turf also came to an end, except for a few elite burials (Holst et al. 2013). A new political and ritual regime with less boasting of power had taken over, probably due to a centralisation of power in fewer hands, but also due to influence from the Lausitz/Lusatian culture. This new regime corresponds to similar changes in Central Europe (Clausing 2005), and the elites now shared international prestige goods of drinking and feasting (Metzner-Nebelsick 2003).

Once this new trading network was established it flourished and continued during Period IV of the Nordic Bronze Age (Kristiansen 1998, figs 42 \& 45). During Period III it exhibited the same characteristics as the former Period II network: there is a concentration of swords and Aegean imports/imitations in Slovakia/the Carpathian Basin, and then there is another heavy concentration in Denmark and Mecklenburg, with an empty stretch of several hundred kilometres in between. Again it suggests directional and regular trade connections between these two rich and powerful regions. Hammered bronze vessels of various types produced in the Carpathian zone reached the Nordic zone in quite large numbers, and testify to the elite level of trade (Metzner-Nebelsick 2003). In the Nordic zone Mecklenburg rose to dominance during Period III, and it is therefore not surprising that hostilities would occur especially in this region, as witnessed in Tollense (cf. Jantzen et al. 2011). In the following we shall therefore discuss in more detail the possible historical processes leading up to this major change in trade routes (and religious beliefs), accompanied by social disruption, warfare, and migrations, during the 13th-12th centuries BC.

\section{CENTRAL EUROPE \& THE EASTERN MEDITERRANEAN DURING THE 13TH-12TH CENTURIES BC: THE HISTORICAL PROCESSES AT WORK}

The rise of the Late Bronze Age warrior aristocracy in temperate Europe and its expansion especially after $1300 \mathrm{BC}$ must be explained with respect to the region's position on the periphery of the more advanced and richer centres of the Mediterranean Basin 
K. Kristiansen \& P. Suchowska-Ducke CONNECTED HISTORIES 1500-1100 BC

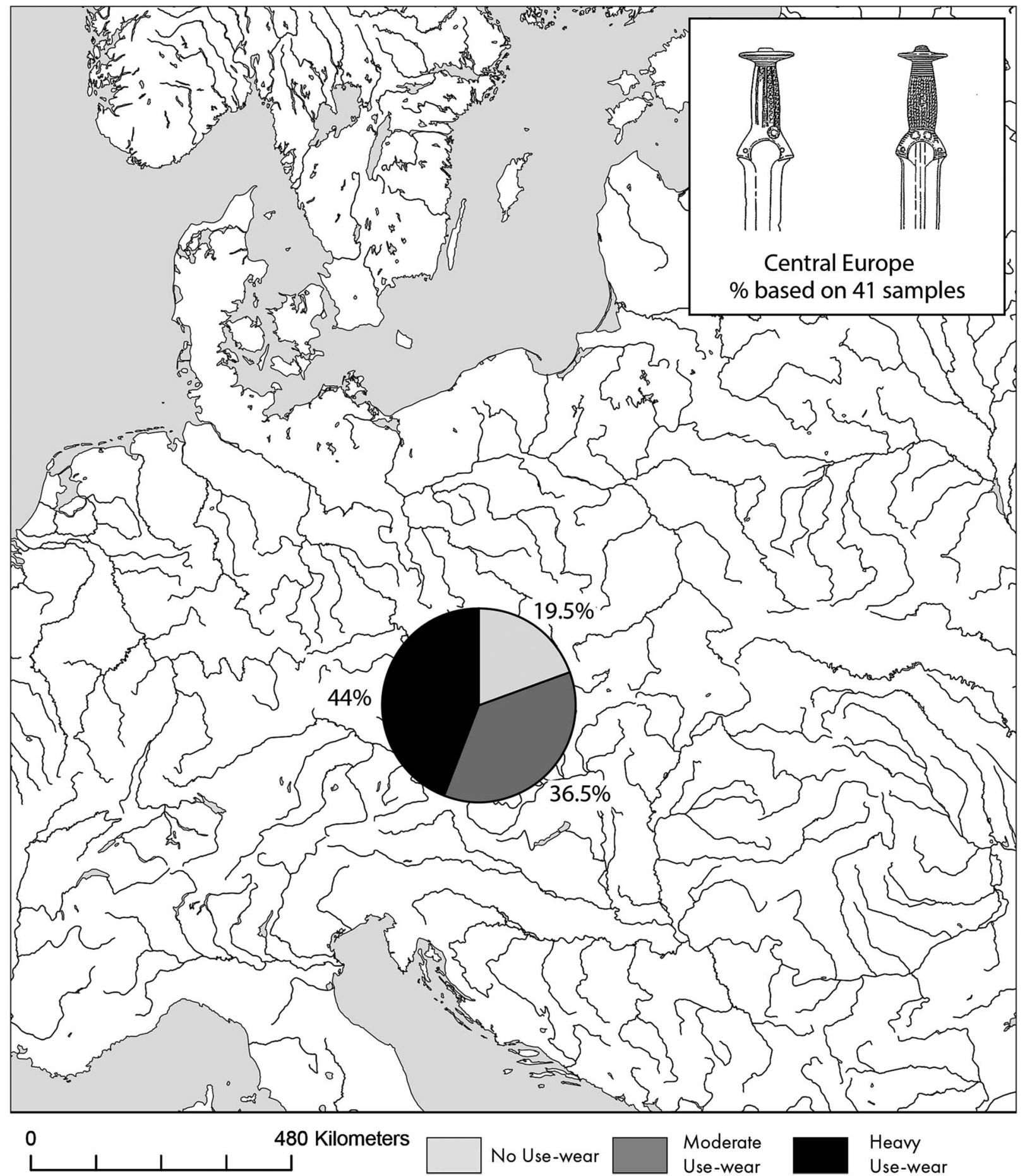

Fig. 9.

Use-wear of Riegsee swords showing an increasing number of heavily worn swords, indicating decreasing supplies of metal. Digital drawing by Richard Potter 


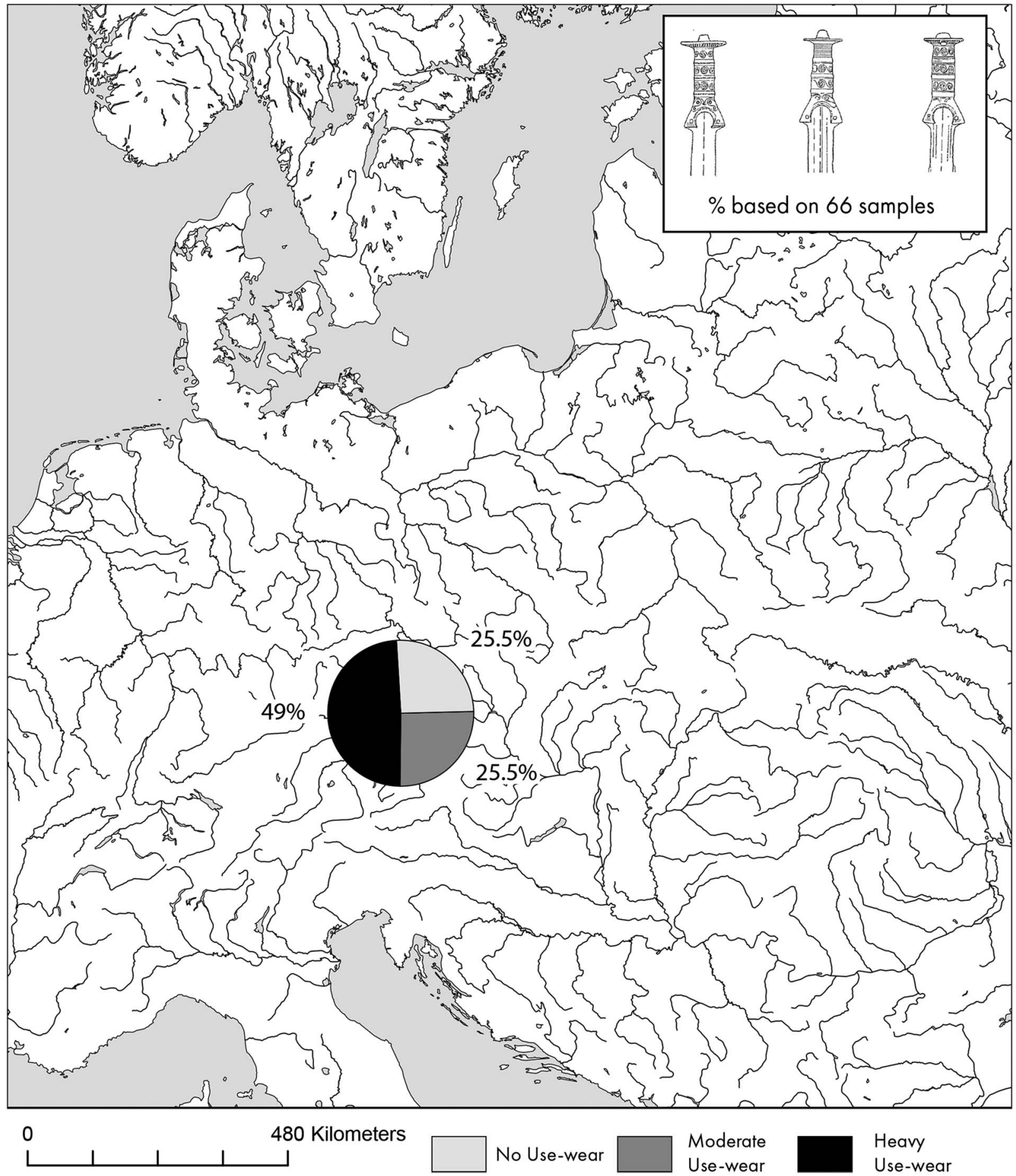

Fig. 10.

Use-wear of 'Dreiwulstschwerter' now showing half of the swords are heavily worn. Fig. 12 corresponds to similar figures for Nordic full-hilted swords during Period III. Digital drawing by Richard Potter 


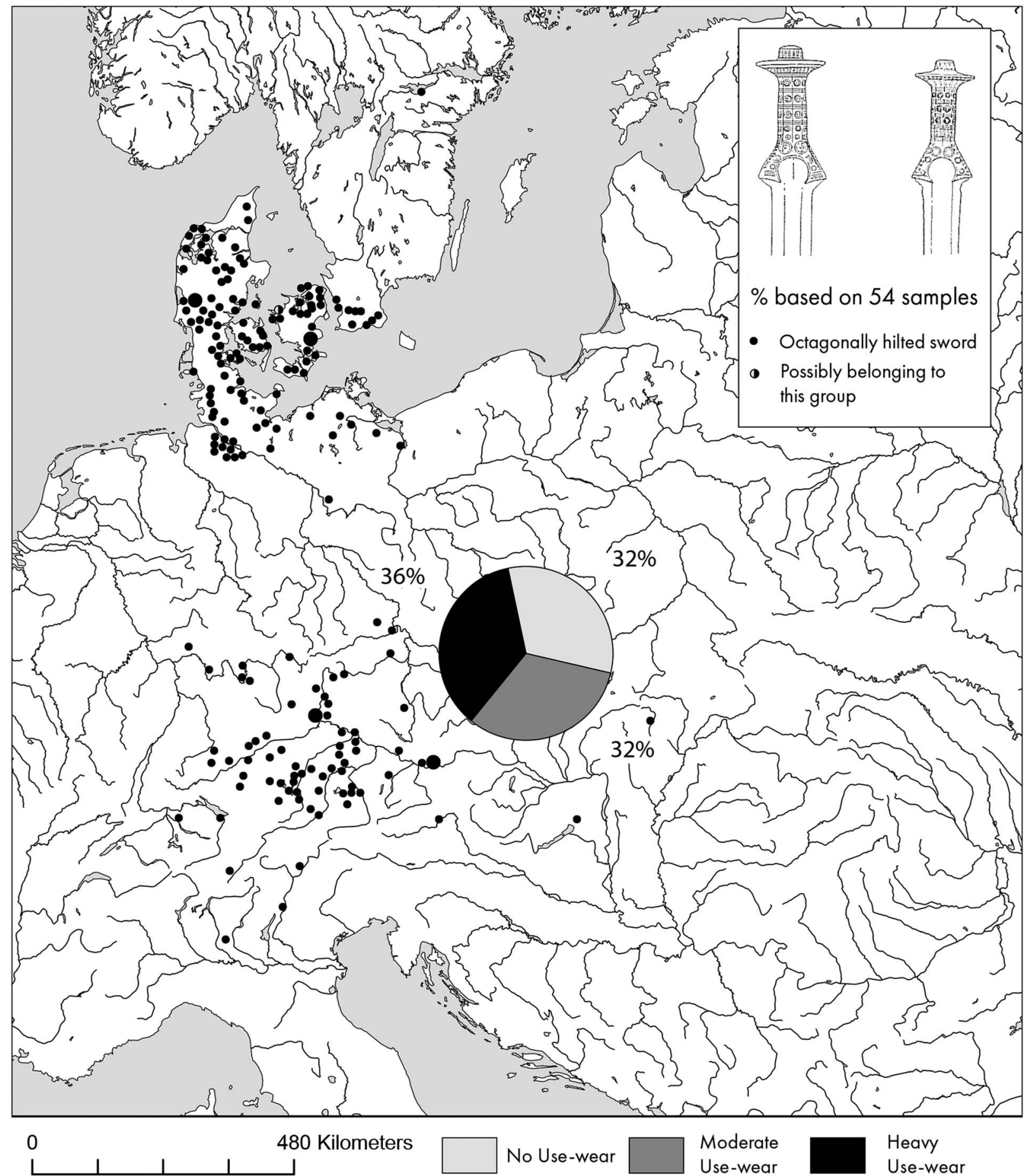

Fig. 11.

Use-wear on Period II octagonal-hilted swords, which shows an even distribution between swords with no use-wear on the hilt, with moderate use-wear, and with heavy use-wear. It corresponds quite well to the Danish situation during Period II, even if some regions had more unused swords (Kristiansen 1978, fig. 2). Digital drawing by Richard Potter 


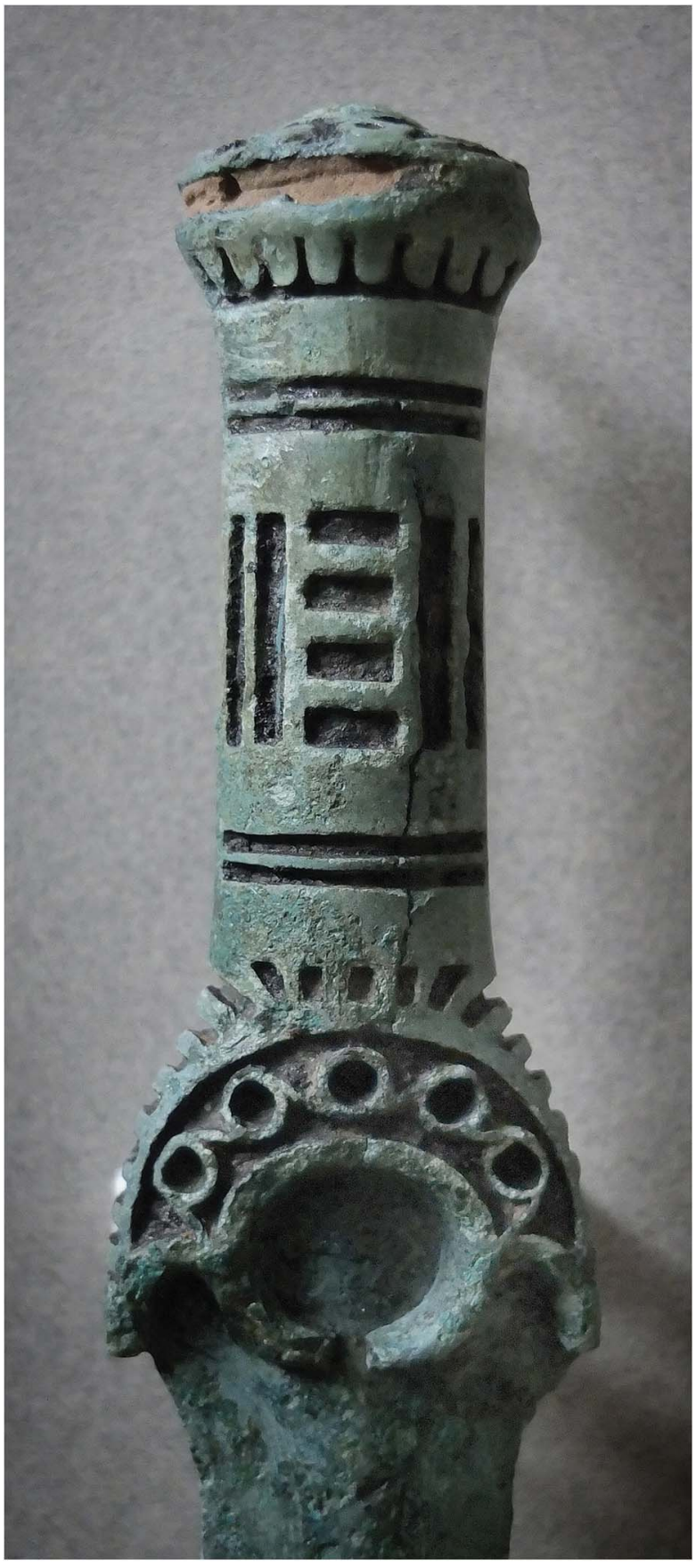

Fig. 12.

Photo of a full-hilted Period III sword from Thy in Denmark, with a hilt completely worn down to the clay core. Photo by Klaus Madsen, Thisted museum

(Kristiansen \& Larsson 2005). It coincides with the emergence of the Urnfield Culture, characterised by intensive development and great mobility. The most important historical question, then, is how these processes in the European peripheries were related to the contemporaneous developments in the palatial centres of the Mediterranean Basin. Indeed, what makes this epoch in European history most remarkable are the dramatic events associated with the influx of the 'Sea Peoples' and the eventual destruction of the palatial centres of the South after 1200 BC. However, we can only understand the background to the Sea Peoples, and contemporary overland migrations through the Balkans, by probing more deeply into those large-scale changes that took place in temperate Europe from the beginning of the Urnfield period between 1350 and $1250 \mathrm{BC}$ as they form a necessary prelude to what happened after $1200 \mathrm{BC}$.

While the full-hilted sword of Riegsee type and its successors never left the Central European mainland, the flange-hilted sword, also known as Naue II, is an international warrior's weapon that was in use from the Aegean to Scandinavia (see Fig. 1). This begets the question of what exactly it was that made these swords so much more globally popular, and what made them one of the most important sources of evidence for the role of travelling mercenaries and their impact on Late Bronze Age societies across Europe?

New forms of warfare and new forms of more centralised government go hand-in-hand. Traditionally Bronze Age warfare was mostly local, and linked to raids and oppression using small war bands of typically 15-20 lance carrying infantries, with one or two sword carrying commanders. From Period III they might have been on horseback. This pattern of small war bands can be traced from the early Middle Bronze Age and down to the Late Bronze Age (Harding 2007; Vandkilde 2013a). What we see in the Urnfield period is the beginning of more organised battles with hundreds or even thousands of warriors. It only makes sense if you were able to control your enemy's territory after a conquest, and to do that there had to be centralised settlements housing all major institutions and functions needed to govern and control a larger territory, eventually supported by smaller local forts. This form of government started on a smaller scale in the Carpathian Basin with the tell cultures during the Middle Bronze Age (Earle \& Kristiansen 2010; Uhner 2012), and by the 14 th century reached a new momentum in the very same region, which led to new settlements and increased population. 


\section{K. Kristiansen \& P. Suchowska-Ducke CONNECTED HISTORIES 1500-1100 BC}

New forms of settlement \& increasing population densities

Cornesti-Iarcuri in Transylvania represents a new form of proto-urban settlement of a size never seen before or after, that is until the historical period. This settlement, nearly $6 \mathrm{~km}$ across $\left(1733 \mathrm{ha} / 17 \mathrm{~km}^{2}\right)$, had four fortification lines and an inner settlement with a diameter of c. $2 \mathrm{~km}$ (Szentmiklosi et al. 2011). Magnetic mapping and preliminary excavations suggest a dense and wellorganised settlement of urban character. For the fortification walls alone an estimated 824,000 tonnes of earth had to be moved. Archaeological material and a few radiocarbon dates suggest the construction took place during the earlier Urnfield Culture (there are only three radiocarbon dates of the later burning phase, made on wood from burnt oak beams whose inbuilt age should be considered). Some time after, probably during HaA1, the settlement was burned down in a heavy fire and apparently abandoned. There is still a long way to go before we fully understand this mega-site; archaeological work so far is preliminary, but it suggests that something completely new was taking place in terms of the organisation of large populations. There is also evidence of two smaller fortified sites, $1 \mathrm{~km}$ across, that might have been part of this new political structure as well. We must envisage these mega-sites as being part of a political centralisation process, a complex chiefdom, or archaic state that perhaps failed. In the vicinity we also find corresponding rich graves from the same period, which are contemporary with the Bernstorf fortification and its later devastation. Furthermore, such population surplus would be a natural primary instigator for later migrations, especially if the settlement was abandoned, in part or entirely, during the 12th century BC.

Such migrations correspond with evidence from Tollense in fertile Mecklenburg (Jantzen et al. 2011). Here a huge army of several hundred, perhaps several thousand, warriors met with a defending army, and a battle raged along the small river over several kilometres (Jantzen et al. 2011; 2014). The attackers apparently came from the south; Price (2014) shows that c. $50 \%$ was non-local, but this figure could be higher. They used bronze arrowheads and also horses for the officers - in short, they were an organised army. Dating of the battle by radiocarbon so far places it in the middle of the 13th century BC. Such a migration to the Nordic cultural zone could be the kind of event that broke the old exchange network to southern Germany and established a new connection to the south towards Slovakia and the Carpathians.
It suggests that Bronze Age societies were highly organised, but also that overpopulation and new forms of political authority might lead to migrations out, first to the north, later to the south. Such migrations further provided part of an explanation for a temporary collapse of the metal trade in the 13th century BC, as evidenced by the dominance of heavily worn swords in the Nordic realm (Fig. 12).

\section{New forms of agrarian intensification: the creation of larger food supplies \& a new political economy} New crops and more intensive agrarian regimes are introduced during the Urnfield period, and they transformed landscapes on a large scale (Bartelheim \& Stäuble 2009); for example, cutting down forest along river valleys to create fields made them prone to erosion (French 2010). Some of these new agrarian strategies could well have been inspired from the south, but more importantly they allowed more people to be fed than during the predominantly herding economies of the Tumulus culture.

We may thus conclude that during the 13th century $\mathrm{BC}$ societies in Central Europe underwent not only a religious reform with the onset of the Urnfield culture, but they also underwent economic and political reforms - in short a new political economy with a higher degree of centralisation was established, and consequently many later settlements were now fortified (Harding 2000, 296). The more extreme centralisation processes may have succeeded only in the heartland of Central Europe, as is evidenced by the mega-site Cornesti-Iarcuri in Transylvania. Such centralisation processes of large populations might have spurred new migrations to the north, the west, and later to the south when the mega settlements were abandoned. A similar development of a more hierarchical settlement structure followed by more violence is evidenced also in the Terramare Culture in northern Italy (Cansi et al. 2009). Here a large population concentration reached a tipping point around $1200 \mathrm{BC}$, and more than 100,000 people abandoned their homes; some of them settled elsewhere in Italy, while others evidently became part of the Sea Peoples (Cardarelli 2009; Kristiansen in press). Such build up of populations in northern Italy and Central Europe provides a necessary background for understanding how Bronze Age societies in Europe could provide the population surplus for the huge migrations at land and sea that came to characterise 
the 12th century $\mathrm{BC}$, and led to the onset of a Dark Age in Anatolia, Greece, and in the eastern Mediterranean.

\section{Centre-periphery dynamics}

The archaeological evidence clearly indicates that what happened in the Aegean world during the 13th and 12th centuries $\mathrm{BC}$ was not just a local chain of temporary economic and social disruptions, but also a catastrophic sequence of events that eventually affected most of the continent. The stability and growth that initially characterised the Aegean Late Bronze Age vanished, giving way to the decline of the palatial societies. Most intriguingly, it seems that the appearance of temperate European mercenaries and settlers coincided with, promoted, or even caused these significant political, social, and economic changes in the Mediterranean Basin, resulting in a partial collapse of exchange and communication networks that ultimately brought about not only the decline of the once mighty Mycenaean culture, but also the citystates of the eastern Mediterranean (Muhly 1992; Drews 1993; Bachhüber \& Roberts 2009).

There is little indication that an indigenous aristocracy survived in the south that would have been able to re-manifest its social position and wealth during that time. There are, however, some exceptions. These are the so-called 'warrior graves', most of them recorded in Achaea during the LH III C (1200-1100 BC; Deger-Jalkotzy 2006; Giannopoulos 2008). They contained swords of Naue II type along with Mycenaean swords and other weaponry such as daggers, knives, spears, greaves, helmets, and shields. They also contained metal vessels, dress fasteners, and jewellery, as well as tweezers, combs, and razors. These graves testify to attempts at establishing a new hierarchical social organisation in post-palatial society as well as the rise of a distinct class of warriors whose function had changed in line with the changing circumstances (Deger-Jalkotzy 2006). These were the warriors who, through their military prowess, were able to grasp the opportunities that came with shifting social status and political power. It may be speculated that some of these new 'warrior princes' were indeed mercenaries of northern origin that stayed in Greece to become local rulers (Giannopoulos 2008). This view is supported by the fact that most of the weapons (usually a sword accompanied by one or more spears) found in these graves were European types (Jung \& Mehofer 2013), but swords of the Aegean types F and
G have been found as well. However, as Eder (1999) points out, Mycenaean types of weapons were found mostly in peripheral regions (such as Thessaly), while Naue II swords were mainly found in the warrior tombs of the Peloponnese and on the Aegean Islands. Thus, the phenomenon of the 'warrior graves' reflects a deeply rooted change in the social and economic spheres of Mycenaean Greece that originated in the collapse of the palatial system (Deger-Jalkotzy 2006).

In a broader view, the involvement of the European warriors in a 'globalised' network of power and wealth can be demonstrated by the diverse archaeological finds from Naue II contexts, such as Baltic amber, dress fasteners, toiletries, and weapons of so-called 'northern origin' that have been found in the Aegean and eastern Mediterranean (cf. Harding 1984; Bouzek 1985; Czebreszuk 2011; SuchowskaDucke in press). Furthermore, the cargoes of the aforementioned shipwrecks of Uluburun and Cape Gelidonya indicate that warriors from the North were present on board. Such a presence among the crew of the Uluburun is attested to by an Italian sword of Pertosa type, six European-type spearheads, a globular bronze pin, a mace with closest parallels in the northern Balkans, and 41 beads of Baltic amber (Pulak 2001). On board the Cape Gelidonya vessel a genuine flange-hilted sword of Naue II type was found (Bass 1991). It is very likely that such items belonged to a foreign warrior whose hired role might have been to protect the traders on their mercantile mission.

During the 13th century the peripheries closer to the Mycenaean and Cypriot palaces were thus increasingly drawn into their realm through a mix of trade, war service by mercenaries, and eventually also some dispositions of people as slaves (Kristiansen 1998, fig. 211; Mederos Martin 2009; Bouzek 2011). In the Terramare this is testified by the appearance of Mycenaean pottery during the 13th century (Radina \& Recchia 2010), just as we find Italian type flange-hilted swords from travelling warriors in several places in the eastern Mediterranean (Jung 2009; Jung \& Mehofer 2009; 2013). One such sword was found on the Uluburun ship, which led Susan Sherratt (2003) to see this movement as the onset of a more dynamic historical situation, where the palaces had less control and private enterprises flourished. However, others have criticised this view and pointed out that palaces were in reality also private enterprises, just on a larger scale (Routledge \& McGeough 2009). Be that as it may, during the 13th century 


\section{K. Kristiansen \& P. Suchowska-Ducke CONNECTED HISTORIES 1500-1100 BC}

we see an increased interaction between the eastern Mediterranean civilizations and the European hinterlands, from the Balkans (Falkenstein 2012/13; Aslaksen 2013) further on to the Carpathians, and via sea routes to northern Italy. Northern Italian Peschiera daggers and early violin bow fibulae used on dress accompanied these movements and show that people rather than goods were travelling (Terzan 2007, table xxxiv). This is also supported by Italian impasto pottery in LH III B contexts at Tiryns, Midea, and Mycenae (Jung \& Mehofer 2013, 184). After 1200 вС these very same peripheries for reasons yet unknown started to migrate towards the centres of civilisation, at land and at sea. We should probably envisage these historical processes much in the same way as later Celtic and Viking migrations, which channelled surplus populations into seasonal trading and raiding alternating with war service leading to conquest and migration when conditions were ripe.

\section{CONCLUSION}

During the Bronze Age, especially from the 16th century BC onward, vast networks of communication existed, transforming physical geography into social geographies. Economic and technological innovations diffused rapidly, flattening 'cultural gradients' and removing borders to trade, exchange, and travel (Harding 1984; Bouzek 1985; Kristiansen \& Larsson 2005; Vandkilde 2013b). The starting point for this investigation was formed by the premises that:

a. pan-European economic and political interdependence can be traced back at least to the Bronze Age;

b. there exists a strong correlation between traders and warriors, which can be used as proxy evidence for cross-cultural communication in the archaeological record; and

c. long-distance mobility influenced central and peripheral regions alike.

We were able to verify all of these premises with two case studies of shifting interregional trading and warrior networks, backed by political alliances. We could further demonstrate that interactions of connected societies are never one-directional: European societies increasingly adopted features from the palatial centres in the eastern Mediterranean, which in turn adopted both warriors and valuable products from the European hinterlands. The final collapse of the centres in the eastern Mediterranean undoubtedly stands testimony to this type of connected fate.

\section{Endnotes}

${ }^{1}$ The flange-hilted sword was, from the very beginning of the 15th century BC, shared from the Aegean to the Nordic area, and there are, among the Central and Northern European swords, a variety with parallel flanges that resembles the Mycenaean type (Kristiansen \& Larsson 2005, fig. 47). Thus it seems that the inspiration for this sword type was rather in the Aegean (Randsborg 1967). With the Naue II flange-hilted sword the picture changes. Now the origin is in Central Europe, or perhaps Italy, and its distribution is much wider than type I flange-hilted swords. Typologically speaking, flange-hilted swords belong to the so-called Griffzungenschwerter family of European swords, a very common and popular type of weaponry in the Bronze Age. More than 1100 specimens of this artefact class are known from across Europe and the eastern Mediterranean (SuchowskaDucke 2015). Rather unsurprisingly, given the extent of their spread, several typological classification schemes of Naue II swords have been presented in the academic literature. The following types are in general considered to be members of the Griffzungenschwerter family of swords; from Central Europe: Nenzingen (Cowen 1955), Reutlingen (Schauer 1971), and Sprockhoff IIa (sometimes also IIb; Sprockhoff 1931), Stätzling (Schauer 1971), Erbenheim and Letten(er) (Cowen 1955); from Italy: Cetona (Bianco Peroni 1970, 62-5), and also Frasinetto (Schauer 1974); and from Greece and the Eastern Mediterranean: Naue II type A, B, and C (Kilian-Dirlmeier 1993) as well as Catling type I, II, III, and IV (Catling 1961).

This diversity of typological classification schemes and the variability of the chronological resolution within the enormous geographical range of the distribution of flange-hilted swords, and not least the lack of absolute dates, pose a challenge to any attempt at establishing a global chronological sequence for the spread of Naue II swords. However, the large sample size allows for the identification of some general trends (Fig. 3), even when considering the effect of preservation bias. Overall, the chronological evidence suggests that the flange-hilted swords of Naue II type originated in the region of the eastern Alps and the Carpathian Basin, where they came into widespread use by the beginning of the 13th century BC. The earliest examples of swords identifiable as flange-hilted swords have been dated to $\mathrm{Br}$ $\mathrm{C} 2 / \mathrm{D}$, and come from burials in Mosonszolnok (two examples) and Csabrendek (one example) in Hungary (Kemenczei 1988, 54, 59). Relatively early Naue II specimens also come from other parts of Central Europe (Br D/HaA1; Schauer 1971; Wüstemann 2004) and from Italy (Bronzo Recente; cf. Bianco Peroni 1970), as well as from the Mediterranean Basin examples from Mycenae (Krzyszkowska 1997) and Kos (Morricone 1966) are both dated to LH III B. However, most of the examples that were found across the European continent date between the late 13th and 11th centuries BC (Catling 1961; 
Bouzek 1985; Colquhoun \& Burgless 1988; Bader 1991; KilianDirlmeier 1993; Harding 1995; Wüstemann 2004). According to Kilian-Dirlmeier (1993) Naue II type swords in Greece were still produced during the Iron Age.

${ }^{2}$ The use-wear analysis on swords was carried out by Kristian Kristiansen, and the documentation and analysis of Naue II swords was carried out by Paulina Suchowska-Ducke. Kristian Kristiansen used the drawings in von Quilfeldt (1995) for the use-wear classification of Central European full-hilted swords, as the drawings were sufficiently accurate. This was based on tests with swords from eastern Central Europe, documented by Kristian Kristiansen. All use-wear analyses on flange-hilted swords were done in museums in Denmark, Hungary, Romania, and Austria.

\section{BIBLIOGRAPHY}

Aner, E., Kersten, K. \& Willroth, K.-H. 2001. Die Funde der älteren Bronzezeit des nordischen Kreises in Dänemark, Schleswig-Holstein und Niedersachsen. Vol. XI, Thisted Amt. Neumünster: Karl Wachholtz

Aner, E., Kersten, K. \& Willroth, K.-H. 2011. Die Funde der älteren Bronzezeit des nordischen Kreises in Dänemark, Schleswig-Holstein und Niedersachsen. Vol. XX, Kreis Segeberg. Copenhagen: Verlag Nationalmuseum

Aslaksen, O.C. 2013. Global and Local in Late Bronze Age Central Macedonia: economy, mobility and identity. Gotarc Series B, no. 61. Gothenburg: University of Gothenburg

Astour, M.C. 1972. The merchant class of Ugarit. In D.O. Edzard (ed.), Rencontre Assyriologique Internationale, Munchen, 29. Juni bis 3. Juli 1970, 11-26. Munich: C.H. Beck

Astour, M.C. 1981. Ugarit and the great powers. In G.D. Young (ed.), Ugarit in Retrospect: fifty years of Ugarit and Ugaritic, 3-29. Winona Lake IN: Eisenbrauns

Bachhüber, C. \& Roberts, R.G. (eds). 2009. Forces of Transformation: the end of the Bronze Age in the Mediterranean. Oxford: Oxbow Books

Bader, T. 1991. Die Schwerter in Rumänien. Stuttgart: Prähistorische Bronzefunde 8

Barjamovic, G., Hertel, T.K. \& Larsen, M.T. 2013. Ups and Downs at Kanesh: chronology, history and society in the Old Assyrian period. Old Assyrian Archives Studies 5. Leiden: Nederlands Instituut voor het Nabije Ossten

Bartelheim, M. \& Stäuble, H. (eds). 2009. The Economic Foundations of the European Bronze Age. Rahden/Westfalen: Forschungen zur Archäometrie und Altertumswissenschaft 4

Bass, G.F. 1991. Evidence of trade from Bronze Age shipwrecks. In Gale (ed.), 1991, 69-82

Bech, J.-H. in press. How much amber? In J.-H. Bech, B.V. Eriksen \& K. Kristiansen (eds), Bronze Age Settlement and Land Use in Thy, Northwest Denmark. Højbjerg/Aarhus: Jutland Archaeological Society/Aarhus University Press

Bianco Peroni, V. 1970. Die Schwerter in Italien/Le Spade nell'Italia continentale. Munich: Prähistorische Bronzefunde 4
Bietti Sestieri, A.M. 1988. The 'Mycenaean connection' and its impact on the central Mediterranean societies. Dialoghi di Archeologia 6, 23-51

Blake, E. 2008. The Mycenaeans in Italy: a minimalist position. Papers of the British School at Rome 76, 1-34

Bouzek, J. 1985. The Aegean, Anatolia and Europe: cultural interrelations in the second millennium $B C$. Gothenburg: Studies in Mediterranean Archaeology 29

Bouzek, J. 2011. Prehistory of Europe as Seen from its Centre: Czech lands from Paleolithic to the end of the La Tène period in European context. Prague: Studia Hercynia XV/1

Briggs-Nash, D. 2006. Servants at a rich man's feast: early Etruscan household slaves and their procurement. Etruscan Studies 9(2002-3), 153-76

Briggs-Nash, D. 2007. Home truths from travellers' tales. In C. Gosden, H. Hamerow, P. de Jersey \& G. Lock (eds), Communities and Connections: essays in honour of Barry Cunliffe, 15-29. Oxford: Oxford University Press

Bryce, T. 2002. Life and Society in the Hittite World. Oxford: Oxford University Press

Buchholz, H.-G. 1983. Doppeläxte und die Frage der Balkanbeziehungen des Ägäischen Kulturkreises. In A. Poulter (ed.), Ancient Bulgaria, 43-134. Nottingham: University of Nottingham

Bunnefeld, J.-H. 2014. Der Häuptling und sein Schwert? Anmerkungen zur soczilaen Stellung des Schwertträgers in der älteren nordischen Bronzezeit. In T. Link \& H. Peter-Röcher (eds), Gewalt und Gesellschaft. Dimensionen der Gewalt in ur- und frühgeschichtlicher Zeit. Internationale Tagung vom 14.-16. März 2013 an der Julius-Maximilians-Universität Würzburg, 133-43. Bonn: Universitätsforschungen zur Prähistorischen Archäologie 259

Bunnefeld, J.-H. \& Schwenzer, S. 2011. Traditionen, Innovationen und Technologietransfer-zur Herstellungstechnik und Funktion älterbronzezeitlicher Schwerter in Niedersachsen. Praehistorische Zeitschrift 86, 207-53

Burns, B.E. 2010. Mycenaean Greece, Mediterranean Commerce, and the Formation of Identity. Cambridge: Cambridge University Press

Bähr, V., Krause, R. \& Gebhard, R. 2012. Neue Forschungen zu den Befestigungen auf dem Bernstorfer Berg bei Kranzberg. Bayerische Vorgeschichtsblätter 77, $5-41$

Caesar, J. 1869. Gallic Wars, in Commentarii de Bello Gallico. Trans. W.A. McDevitte \& W.S. Bohn. New York: Harper \& Brothers

Cansi, A., Gaspari, E. \& Maino, C. 2009. Cutmarks da lama metallica sui resti scheletrici degli armati dela necropoli del Bronzo medio e recente di Olmo di Nogara (Verona). Traumi inflitti, trapanazioni terapeutische e leione postdeposizionali. Bollettino del Museo Civico di Storia Naturale di Verona 33, 133-48

Cardarelli, A. 2009. The collapse of the Terramare culture and the growth of new economic and social systems during the Late Bronze Age in Italy. Scienze dell-antichita Storia Archeologia Antropologia 15, 449-520

Casson, L. 1995. Ships and Seamanship in the Ancient World. Baltimore MD: Johns Hopkins University Press 


\section{K. Kristiansen \& P. Suchowska-Ducke CONNECTED HISTORIES 1500-1100 BC}

Catling, H.W. 1961. A new bronze sword from Cyprus. Antiquity 35, 115-22

Cazzella, A. \& Recchia, G. 2009. The 'Mycenaeans' in the central Mediterranean: a comparison between the Adriatic and the Tyrrhenian seaways. Pasiphae 3, 27-40

Clausing, C. 2003. Ein urnenfelderzeitlicher Hortfund von Slavonski Brod, Kroatien. Jahrbuch des RömischGermanischeb Zentralmusems Mainz 50, 47-205

Clausing, C. 2005. Macht und Grab - zum Wagengrab von Künzing in Niederbayern und seiner Stellung im urnenfelderzeitlichen Mitteleuropa. Vorträge des Niederbayerischen Archäologentages 23, 75-103

Clifford, J. 1992. Travelling cultures. In L. Grossberg, C. Nelson \& P. Treichler (eds), Cultural Studies, 96-116. London: Routledge

Cline, E.H. 1991. A possible Hittite embargo against Mycenaeans. Historia Einzelschrift 40, 1-9

Cline, E.H. 2009. Sailing the Wine-Dark Sea: international trade and the Late Bronze Age Aegean. Oxford: British Archaeological Report S591

Cline, E.H. 2014. 1176 - The Year Civilization Collapsed. Princeton NJ: Princeton University Press

Cohen, R. \& Westbrook, R. (eds). 2000. Amarna Diplomacy: the beginnings of international relations. Baltimore MD: Johns Hopkins University Press

Colquhoun, I. \& Burgless, C.B. 1988. The Swords of Britain. Munich: Prähistorische Bronzefunde 5

Cowen, J.D. 1955. Einführung in die Geschichte der bronzenen Griffzungenschwerter in Süddeutschland. Bericht der Römisch-Germanischen Kommission des Deutschen Archëologischen Instituts (BRGK) 33, 52-155

Cupito, M. 2006. Tipocronologia del Bronzo medio e recente tra l'Adige e il mincio sulla base delle evidenze funerary. Padova: Saltuarie al laboratorio del Piovego 7

Czebreszuk, J. 2011. Bursztyn w kulturze mykeńskiej: zarys problematyki badawczej. Poznań: Wydawnictwo Poznańskie

Czebreszuk, J. 2013. Mysterious raw material from the far north: amber in Mycenaean culture. In S. Bergerbrant \& S. Sabatini (eds), Counterpoint: essays in archaeology and heritage studies in honour of Professor Kristian Kristiansen, 557-63. Oxford: British Archaeological Report S2508

Deger-Jalkotzy, S. 2006. Late Mycenaean Warrior Tombs. In S. Deger-Jalkotzy \& I.S. Lemos (eds), Ancient Greece: from the Mycenaean palaces to the age of Homer, 151-79. Edinburgh: Edinburgh University Press

Dietrich, L. 2010. Eliten der frühen und mittleren Bronzezeit in südostlichen Karpatenbecken. Praehistorische Zeitschrift 85, 191-206

Drews, R. 1993. The End of the Bronze Age: changes in warfare and the catastrophe ca. 1200 BC. Princeton NJ: Princeton University Press

Earle, T. 2002. Bronze Age Economics: the beginnings of political economies. Boulder CO: Westview Press

Earle, T. \& Kristiansen, K. 2010. Organising Bronze Age societies: concluding thoughts. In T. Earle \& K. Kristiansen (eds), Organising Bronze Age Societies, 218-56. Cambridge: Cambridge University Press
Earle, T., Ling, J., Uhnér, L., Stos-Gale, Z. \& Melheim, L. 2015. The political economy and metal trade in Bronze Age Europe: understanding regional variability in terms of comparative advantages and articulations. European Journal of Archaeology 18(4), 633-57

Eder, B. 1999. Late Bronze Age Swords from Ancient Elis. In R. Laffineur (ed.), Polemos. Le Contexte Guerrier en Égée à l'âge du Bronze. Actes de la $7 e$ rencontre égéenne internationale, Université de Liège 14-17 avril 1998, 443-8. Liege: Aegaeum 19

Eder, B. 2003. Patterns of contact and communication between the regions south and north of the Corinthian Gulf in LH IIIC. In N. Kyparissis-Apostolika \& M. Papakonstantinou (eds), The Periphery of the Mycenaean World, 37-54. Athens: Ministry of Culture

Endrighkeit, A. 2014. Älter- und mittelbronzezeitliche Bestattungen zwischen Nordischem Kreis und süddeitscher Hügelgräberkultur. Bonn: Gesellschaftstrukturen und kulturhistorische Beziehungen. Frühe Monumentalität und soziale Differenzierung, Band 6

Falkenstein, F. 2012/13. Kulturwandel und Klima im 13/12 Jahrhundert $\mathrm{v}$ Chr - Das Beispiel Kastanas in Nordgriechenland. Offa, Von Sylt bis Gastanks. Festschrift für Helmut Johannes Kroll 69/70, 505-25

Foltiny, S. 1964. Flange-hilted cutting swords of bronze in Central Europe, Northeast Italy, and Greece. American Journal of Archaeology 68, 247-58

Frei, K.M., Mannering, U., Kristiansen, K., Allentoft, M.E., Wilson, A.S., Skals, I., Tridico, S., Nosch, M.L., Willerslev, E., Clarke, L. \& Frei, R. 2015. Tracing the life story of a Bronze Age girl with high societal status. Nature Scientific Report 5, no. 10431

French, C.A.I. 2010. The palaeo-environments of Bronze Age Europe. In T. Earle \& K. Kristiansen (eds), Organising Bronze Age Societies, 34-56. Cambridge: Cambridge University Press

Galanki, I., Tomas, H., Galanaki, Y. \& Laffineur, R. (eds). 2007. Between the Aegean and the Baltic Seas: prehistory across borders. Liège/Austin TX: Aegaeum 27

Gale, N.H. (ed.) 1991. Bronze Age Trade in the Mediterranean. Jonsered: Studies in Mediterranean Archaeology 90

Giannopoulos, T. 2008. Die letzte Elite der mykenischen Welt. Achaia in mykenischer Zeit und das Phänomen der Kriegerbestattungen im 12.-11. Jahrhundert $v$. Chr. Bonn: Universitätsforschungen zur prähistorsichen Archäologie Band 152

Giardino, C. 1992. Nuragic Sardinia and the Mediterranean: metallurgy and maritime traffic. In R. Tykot \& T. Andrews (eds), Sardinia in the Mediterranean: a footprint in the sea. Sheffield: Monographs in Mediterranean Archaeology 3

Gibson, D.B. 2011. Chiefdom confederacies and state origins. Social Evolution \& History 10(1), 215-33

Goetze, B.-R. 1984. Die frühesten europäischen Schutzwaffen. Ammerkungen zum Zusammenhang einer Fund-gattung. Bayerische Vorgeschichtsblätter 49, 25-53

Hansen, S. 1991. Studien zu den Metalldeponierungen während der Urnenfelderzeit im Rhein-Main-Gebiet. Bonn: Habelt 
Hansen, S. 1994. Studien zu den Metalldeponierungen während der älteren Urnenfelderzeit zwischen Rhônetal und Karpatenbecken. Bonn: Universitätsforschungen zur prähistorischen Archäologie 21

Harding, A.F. 1984. Mycenaeans and Europe. London: Academic Press

Harding, A.F. 1995. Die Schwerter im ehemaligen Jugoslawien. Stuttgart: Prähistorische Bronzefunde 14

Harding, A.F. 2000. European Societies in the Bronze Age. Cambridge: Cambridge University Press

Harding, A.F. 2007. Warriors and Weapons in Bronze Age Europe. Budapest: Archaeolingua

Heltzer, M. 1988. Sinaranu, son of Siginu, and the trade relations between Ugarit and Crete. Minos 23, 7-13

Hitchkock, L.A. \& Maeir, A.M. 2014. Yo-ho, yo-ho, Seren's life for me! World Archaeology 46(3), 624-40

Holst, M.K., Rasmussen, M., Bech, J.-H. \& Kristiansen, K. 2013. Bronze Age 'Herostrats': ritual, political, and domestic economies in Early Bronze Age Denmark. Proceedings of the Prehistoric Society 79, 1-32

Hughes-Brock, H. 2005. Amber and some other travellers in the Bronze Age Aegean and Europe. In A. Dakouri-Hild \& S. Sherratt (ed.), Autochthon: papers presented to O.T.P. K. Dickinson on the occasion of his retirement, 301-16. Oxford: British Archaeological Report S1432

Hänsel, B. 2007. Ägäische Siedlungsstrukturen in Monkodonja/Istrien? In Galanki et al. (eds) 2007, 149-56

Jantzen, D., Brinker, U., Orschiedt, J., Heinemeier, J., Piek, J., Hauenstein, K., Krüger, J., Lidke, G., Lübke, H., Lampe, R., Lorenz, S., Schult, M. \& Terberger, T. 2011. A Bronze Age battlefield? Weapons and trauma in the Tollense Valley north-eastern Germany. Antiquity 85, 417-33

Jantzen, D., Orschiedt, J., Piek, J. \& Terberger, T. (eds). 2014. Tod im Tollensetal - Forschungen zu den Hinterlassenschaften eines bronzezeitlichen Gewaltkonfliktes in Mecklenburg-Vorpommern 1. Die Forschungen bis 2011. Schwerin: Beiträge zur Ur-und Frühgeschichte MecklenburgVorpommerns 50

Jockenhövel, A. 1991. Räumliche Mobilität von Personen in der mittleren Bronzezeit des westlichen Mitteleuropa. Germania 69, 49-62

Jones, R.E. \& Vagnetti, L. 1991. Traders and craftsmen in the central Mediterranean: archaeological evidence and archaeometric research. In Gale (ed.), 1991, 127-48

Jones, S. 1997. The Archaeology of Ethnicity: constructing identities in the past and the present. London/New York: Routledge

Jung, R. 2005. Aspekte des mykenischen Handels und Produktenaustauschs. In B. Horejs, R. Jung, E. Kaiser \& B. Terzan (eds), Interpretationsraum Bronzezeit. Bernhard Hänsel von seinen Schüler gewidmet, 45-70. Bonn: Habelt

Jung, R. 2009. 'I “bronzi internazionali” ed il loro contesto sociale fra Adriatico penisola Balcanicae coste Levantine. In E. Borgna \& P.C. Guida (eds), From the Aegean to the Adriatic: social organisations, modes of exchange and interaction in postpalatial times (12th-11th B.C.), 129-57. Rome: Quasar
Jung, R. \& Mehofer, M. 2009. A sword of Naue II type from Ugarit and the historical significance of Italian type weaponry in the eastern Mediterranean. Aegean Archaeology 8(2005/2006), 111-35

Jung, R. \& Mehofer, M. 2013. Mycenaean Greece and Bronze Age Italy: cooperation, trade or war? Archäologisches Korrespondenzblatt 43(2), 175-92

Kaul, F. 2013. The Nordic razor and the Mycenaean lifestyle. Antiquity 87, 461-72

Kemenczei, T. 1988. Die Schwerter in Ungarn I (Griffplatten-, Griffangel- und Griffzungenschwerter). Munich: Prähistorische Bronzefunde 6

Kilian-Dirlmeier, I. 1993. Die Schwerter in Griechenland (ausserhalb des Peloponnes), Bulgarien und Albanien. Stuttgart: Prähistorische Bronzefunde 12

Knappett, C. 2011. An Archaeology of Interaction: network perspectives on material culture and society. Oxford: Oxford University Press

Krause, R. 2006/7. Mediterrane Einflüsse in der Frühund Mittelbronzezeit Mitteleuropas-Interaktionsräume und Kulturwandel. Bericht der Bayrischen Bodendenkmalpflege 47/8, 53-65

Kristiansen, K. 1978. The consumption of wealth in Bronze Age Denmark. In K. Kristiansen \& C. Paludan-Müller (eds), New Directions in Scandinavian Archaeology, 158-90. Copenhagen: National Museum Press

Kristiansen, K. 1984. Krieger und Häuptlinge in der Bronzezeit Dänemarks. Ein Beitrag zur Geschichte des bronzezeitlichen Schwertes. Jabrbuch des Römisch-Gremanische Zentralmuseums Mainz 31, 187-208

Kristiansen, K. 1987. From stone to bronze: the evolution of social complexity in Northern Europe 2300-1200 BC. In E.M. Brumfield \& T. Earle (eds), Specialization, Exchange, and Complex Societies, 30-52. Cambridge: Cambridge University Press

Kristiansen, K. 1998. Europe Before History. Cambridge: Cambridge University Press

Kristiansen, K. 2002. The tale of the sword - swords and swordfighters in Bronze Age Europe. Oxford Journal of Archaeology 21(4), 319-32

Kristiansen, K. 2013a. Households in context. Cosmology, economy and long-term change in the Bronze Age of Northern Europe. In M. Madella, G. Kovacs, B. Kulscarne-Berzsenyi \& I.B. Godino (eds), The Archaeology of Households, 235-68. Oxford: Oxbow Books

Kristiansen, K. 2013b. Religion and society in the Bronze Age. In L.B. Christensen, O. Hammer \& D.A. Warburton (eds), The Handbook of Religions in Ancient Europe, 77-92. Durham: Acumen

Kristiansen, K. 2014. Bronze Age identities: from social to cultural and ethnic identity. In J. McInery (ed.), A Companion to Ethnicity in the Ancient Mediterranean, 82-96. Oxford: Wiley Blackwell

Kristiansen, K. in press. Bronze Age trade and migration. In E. Kiriatzi \& C. Knappett (eds), Human Mobility and Technological Transfer in the Prehistoric Mediterranean. Cambridge: British School at Athens Studies in Greek Antiquity 1 


\section{K. Kristiansen \& P. Suchowska-Ducke CONNECTED HISTORIES 1500-1100 BC}

Kristiansen, K. \& Larsson, T. 2005. The Rise of Bronze Age Society: travels, transmissions and transformations. Cambridge: Cambridge University Press

Kristiansen, K. \& Larsson, T. 2007. Contacts and travels during the 2 nd millenium BC. Warriors on the move. In Galanki et al. (eds), 2007, 25-33

Krzyszkowska, O. 1997. Cult and craft: ivories from the Citadel Hause area, Mycenae. In R. Laffineur \& P. Betancourt (eds), TEXNH. Craftsmen, Craftswomen and Craftsmanship in the Aegean Bronze Age, 145-50. Liège/ Austin TX: Aegaeum 16

Lichardus, V.J., Echt, R., Iliev, I.K. \& Christov, C.J. 2002. Die Spätbronzezeit an der Unteren Tundža und die ostägäischen Verbindungen in Südostbulgarien. Eurasia Antiqua 8, 135-84

Ling, J. \& Stos-Gale, Z. 2015. Representations of oxhide ingots in Scandinavian rock art: the sketchbook of a Bronze Age traveller? Antiquity 89, 191-209

Ling, J., Stos-Gale, Z., Grandin, L., Billström, K., HjärthnerHoldar, E. \& Persson, P.-O. 2014. Moving metals II: provenancing Scandianvian bronze artefacts by lead isotope and elemental analysis. Journal of Archaeological Science 41, 106-32

Liversage, D. \& Northover, J.P. 1998. Prehistoric trade monopolies and bronze supply in northern Europe. In C. Mordant, M. Pernot \& V. Rychner (eds), L'atelier $d u$ bronzier en Europe du XX au VIII siècle avant notre ère. Actes $d u$ colloque international Bronze 96, Neuchatel et Dijon I. Les analyses de composition du metal: leur apport a l'archeologie de l'Age du Bronze, 137-50. Paris: CTHS

Lolos, Y.G. 1999. The cargo of pottery from the Point Iria wreck: character and implications. In W. Phelps, Y. Lolos \& Y. Vichos (eds), The Point Iria Wreck: Interconnections in the Mediterranean ca. 1200 BC, 43-58. Athens: Hellenic Institute of Marine Archaeology

Maran, J. 2004. Wessex und Mykene: Zur Deutung des Bernsteins in der Schachtgräberzeit Südgriechenlands. In B. Hänsel \& E. Studenikova (eds), Zwischen Karpaten und Ägäis. Neolithicum und ältere Bronzezeit. Gedenkenschrift für Viera Nemejcova-Pavúkova, 47-65. Rahden/Westfalen: Leidorf

Marinatos, N. 1988. The fresco from Room 31 at Mycenae: problems of method and interpretation. In E.B. French \& K.A. Wardle (eds), Problems in Greek Prehistory, 245-8. Bristol: Bristol Classical Press

Mederos Martin, A. 2009. La crisis del siglo XII a.C. Pueblos del Mar y guerra de Troya ca. 1215-1175 a.C. SPAL. Revista de Prehistoria y Arqueologia de la Universidad de Sevilla 16(2007), 93-153

Metzner-Nebelsick, C. 2003. Ritual und Herrschaft. Zur Struktur von spätbronzezeitlichen Metallgefässdepots zwischen Nord-und Südosteuropa. In C. Metzner-Nebelsick (ed.), Rituale in der Vorgeschichte, Antike und Gegewart, 99-116. Rahden/Westfalen: Leidorf

Militello, P. 2004. Commercianti, architetti ed artigiani: riflessioni sulla presenza egea nella Sicilia sud-orientale. In V. La Rosa (ed.), Le presenze micenee nel Siracusano, 295-335. Padua: Bottega d'Erasmo
Molloy, B. 2010. Swords and swordsmanship in the Aegean Bronze Age. American Journal of Archaeology 114(3), 403-28

Monroe, C.M. 2011. 'From luxuries to anxieties': a liminal view of the Late Bronze Age world-system. In $\mathrm{T}$. Wilkinson, S. Sherratt \& J. Bennett (eds), Interweaving Worlds: systemic interactions in Eurasia 7 th to the 1 st Millennia BC, 87-99. Oxford: Oxbow Books

Moran, W.L. 1992. The Amarna Letters. Baltimore MD: Johns Hopkins University Press

Mordant, C., Rottier, S. \& Saligny, L. 2007. De la notion mobilite au sein des populations, du Bronze Moyen a l'étape initiale du Bronze Final en France orientale (XV-XII siècle avant J.-C.). In H. Richard, M. Magny \& C. Mordant (eds), Environnements et cultures à l'âge du bronze en Europe occidentale, 143-57. Paris: Documents préhistoriques 21

Morkot, R.G. 2007. War and the economy: the international 'arms trade' in the Late Bronze Age and after. In T. Schneider \& K. Szpakowska (eds), Egyptological Stories: a British Egyptological tribute to Alan B. Lloyd on the occasion of his retirement, 169-95. Muenster: Ugarit-Verlag

Morricone, L. 1966. Eleone e Langada: sepolcreti della tarda età del brozne a Coo. ASAtene 27-28, 5-312

Muhly, J.D. 1992. The crisis years in the Mediterranean world: transition or cultural disintegration? In W.A. Ward \& M.S. Joukowsky (eds), The Crisis Years: the 12th Century B.C. from beyond the Danube to the Tigris, 10-26. Dubuque IA: Kendall/Hunt

Mukherjee, A.M., Roßberger, E., James, M.A., Pfälzner, P., Higgitt, C.L., White, R., Peggie, D.A., Azar, D. \& Evershed, R.P. 2008. The Qatna lion: scientific confirmation of Baltic amber in Late Bronze Age Syria. Antiquity 82, 49-59

Müller, J. 2015. Bronze Age social practices: demography and economy forging long-distance exchange. In P. Suchowska-Ducke, S.S. Reiter \& H. Vandkilde (eds), Forging Identities: the mobility of culture in Bronze Age Europe. Oxford: British Archaeological Report S1156

Novák, P. 1975. Die Schwerter in der Tschechoslowakei I. München: Beck

O'Brien, W. 2015. Prehistoric Copper Mining in Europe, 5500-500 BC. Oxford: Oxford University Press

Otto, T., Thrane, H. \& Vandkilde, H. (eds). 2006. Warfare and Society: archaeological and social anthropological perspectives. Aarhus: Aarhus University Press

Palincaş, N. 2007. Contacts with the Aegean and their social impact in the Late Bronze Age in the Lower Danube. In Galanki et al. (eds) 2007, 231-7

Popa, C.I. 2014. Reprezentarea unui lingou de top Keftiu pe o placa de centura din bronz din Transilvania si conexiunile sale. Terra Sebus. Acta Musei Sabesiensis 6, 211-51

Price, T.D. 2014. Isotopic analysis of human tooth enamel from the Tollense Valley. In D. Jantzen, J. Orschiedt, J. Piek $\&$ T. Herberger (eds), Tod im Tollensetal. Forschungen $z u$ den Hinterlassenschaften eines bronzezeitlichen Gewaltkonfliktes in Mecklenburg-Vorpommern. Teil 1: Die Forschungen bis 2011, 223-32. Schwerin: Beiträge zur Ur- und Frühgeschichte Mecklenburg-Vorpommerns Band 50 
Primas, M. \& Pernicka, E. 1998. Der Depotfund von Oberwilflingen. Neue Ergebnisse zur Zirkulation von Metallbarren. Germania 76, 25-65

Pulak, C. 2001. The cargo of the Uluburun ship and evidence for trade with the Aegean and beyond. In L. Bonfante \& V. Karageorghis (eds), Italy and Cyprus in Antiquity 1500-450 B.C., 13-60. Nicosia: Costakis \& Leto Severis Foundation

Radina, F. \& Recchia, G. (eds). 2010. Ambra per Agamennone: indigeni e micenei tra Adriatico, Ionio ed Egeo. Bari: M. Adda

Randsborg, K. 1967. 'Aegean' bronzes in a grave from Jutland. Acta Archaeologica 38, 1-27

Routledge, B. \& McGeough, K. 2009. Just what collapsed? A network perspective on 'palatial' and 'private' trade at Ugarit. In Bachhüber \& Roberts (eds), 2009, 22-9

Ruiz-Galvez Priego, M. \& Galán, E. 2013. A meal for the hero: on the origins of roasted meat, spits and the male ideal. In M.E. Aubet \& P. Sureda (eds), Interaccion social $y$ comercio en la entesala del colonialism, 43-69. Barcelona: Edicions Bellaterra

Sabatini, S. in press. Revisiting Late Bronze Age copper oxhide ingots: meanings, questions and perspectives. In O.-C. Aslaksen (ed.), Local and Global: perspectives on mobility in the Eastern Mediterranean. Athens: Norwegian Institute at Athens Papers

Sandars, N.K. 1983. North and South at the end of Mycenaean Age: an aspect of an old problem. Oxford Journal of Archaeology 2(1), 43-68

Schauer, P. 1971. Die Schwerter in Süddeutschland, Österreich und der Schweiz (Griffplatten-, Griffangelund Griffzungenschwerter). Munich: Prähistorische Bronzefunde 4.2

Schauer, P. 1974. Zu einigen italienischen Schwertern in Westeuropäischen Museen. In H. Müller-Karpe (ed.), Beiträge zu italienischen und griechischen Bronzefunden, 27-32. München: Beck

Sherratt, A.G. 1993. What would a Bronze Age world system look like? Relations between temperate Europe and the Mediterranean in late prehistory. Journal of European Archaeology 1(2), 1-57

Sherratt, S. 2003. The Mediterranean economy: 'globalisation' at the end of the second millennium BCE. In W.G. Dever \& S. Gitin (eds), Symbiosis, Symbolism, and the Power of the Past. Canaan, ancient Israel, and their neighbours from the Late Bronze Age through Roman Palaestina, 37-62. Winona Lake IN: Eisenbrauns

Sherratt, A.G. \& Sherratt, E.S. 1991. From luxuries to commodities: the nature of Mediterranean Bronze Age trading system. In Gale (ed.), 1991, 351-86

Sperber, L. 1999. Zu den Schwertgräbern im westlichen Kreis der Urnenfelderkultur: profane und religiöse Aspekte. In Eliten in der Bronzezeit: Ergebnisse zweier Kolloquien in Mainz und Athen, 605-60. Bonn: Forschungsinstitut für Vor-und Frühgescichte 43

Sprockhoff, E. 1931. Die germanischen Griffzungenschwerter. Berlin: de Gruyter

Steel, L. 2013. Materiality and Consumption in the Bronze Age Mediterranean. London: Routledge
Stockhammer, P.W. 2004. Zur Chronologie, Verbreitung und Interpretation urnenfelderzeitlicher Vollgriffsschwerter. Rahden/Westfalen: Tübinger Texte 5

Suchowska, P. 2009. Communication space of the Northern Pontic area as viewed by Aegeans. Baltic-Pontic Studies $14,156-75$

Suchowska-Ducke, P. 2015. The dissemination of Naue II swords - a case study on long-distance mobility. In P. Suchowska-Ducke, S.S. Reiter \& H. Vandkilde (eds), Forging Identities: the mobility of culture in Bronze Age Europe. Report from a Marie Curie project 2009-2012 with concluding conference at Aarhus University, Moesgaard 2012. Oxford: British Archaeological Report S1156

Suchowska-Ducke, P. In press. The Mycenaeans and Europe: long-distance networks and cross-cultural communication. In O.-C. Aslaksen (ed.), Local and Global: perspectives on mobility in the Eastern Mediterranean. Athens: Norwegian Institute at Athens Papers

Szentmiklosi, A., Heeb, B.S., Heeb, J., Harding, A., Krause, R. \& Becker, H. 2011. Cornesti-Iarcuri - a Bronze Age town in the Romanian Banat? Antiquity 85, 819-38

Tartaron, T. 2013. Maritime Networks in the Mycenaean World. Cambridge: Cambridge University Press

Terzan, B. 2007. Cultural connections between Caput Adriae and the Aegean in the Late Bronze Age and Early Iron Age. In Galanki et al. (eds), 2007, 157-65

Uckelmann, M. \& Mödlinger, M. (eds). 2011. Bronze Age Warfare: manufacture and use of weaponry. Oxford: British Archaeological Report S2255

Uhner, C. 2012. Society and power: political economy in Bronze Age tell-building communities. In M. Jaeger, J. Czebreszuk \& K.P. Fischl (eds), Enclosed Space - Open Society: contact and exchange in the context of fortified settlements in central Europe, 353-70. Bonn: Rudolf Habelt

Van Wijngaarden, G.J. 2012. Trade goods reproducing merchants? The materiality of Mediterranean Late Bronze Age exchange. In J. Maran \& P.W. Stockhammer (eds), Materiality and Social Practice: transformative capacities and intercultural encounters, 61-72. Oxford: Oxbow Books

Vandkilde, H. 2006. Warfare and pre-state societies: an introduction. In T. Otto, H. Thrane \& H. Vandkilde (eds), Warfare and Society: archaeological and social anthropological perspectives, 105-12. Aarhus: Aarhus University Press

Vandkilde, H. 2013a. Warfare in Northern European Bronze Age societies: twentieth-century presentations and recent archaeological research inquiries. In S. Ralp (ed.), The Archaeology of Violence: interdisciplinary approaches, 37-62. New York: State University of New York Press

Vandkilde, H. 2013b. Breakthrough of the Nordic Bronze Age: transcultural warriorhood and a Carpathian crossroad in the sixteenth century BC. European Journal of Archaeology 17(4), 602-33

Varberg, J., Gratuze, B. \& Kaul, F. 2015. Between Egypt, Mesopotamia and Scandinavia: Late Bronze Age glass 


\section{K. Kristiansen \& P. Suchowska-Ducke CONNECTED HISTORIES 1500-1100 BC}

beads found in Denmark. Journal of Archaeological Science 54, 168-81

Vianello, A. 2005. Late Bronze Age Mycenaean and Italic Products in the West Mediterranean: a social and economic analysis. Oxford: British Archaeological Report S1439

Vianello, A. 2009. Late Bronze Age exchange networks in the Western Mediterranean. In Bachhüber \& Roberts (eds), 2009, 44-50

von Quillfeldt, I. 1995. Die Vollgriffschwerter in Süddeutschland. Stuttgart: Prähistorische Bronzefunde 11 Wachsmann, S. 1987. Aegeans in the Theban Tombs. Leuven: Orientalia Lovaniensia Analecta 20

Wachsmann, S. 2013. The Gurob Ship-Cart Model and its Mediterranean Context. Ed Rachal Foundation Nautical Archaeology Series. College Station TX: Texas A\&M University Press
Wahl, J. \& Price, T.D. 2013. Local and foreign males in a late Bronze Age cemetery at Neckarsulm, south-western Germany: strontium isotope investigations. Anthropologischer Anzeiger 70(3), 289-307

Walton, M.S., Shortland, A., Kirk, S. \& Degryse, P. 2009. Evidence for the trade of Mesopotamian and Egyptian glass to Mycenaean Greece. Journal of Archaeological Science 36, 1496-503

Wardle, K.A. 1993. Mycenaean trade and influence in Northern Macedonia. In C. Zerner, P. Zerner \& J. Winder (eds), Wace and Blegen: pottery as evidence for trade in the Aegean Bronze Age 1939-1989, 117-41. Amsterdam: Gieben

Werner, W.M. 1987. Klappschemel der Bronzezeit. Germania 65(1), 29-65

Wüstemann, H. 2004. Die Schwerter in Ostdeutschland. Stuttgart: Prähistorische Bronzefunde 15

\section{RÉSUMÉ}

Histoires liées: dynamiques de l'interaction et du commerce de l'âge du bronze 1500-1100 av. J.-C., de Kristian Kristiansen et Paulina Suchowska-Ducke

L'âge du bronze fut la première époque au cours de laquelle des sociétés se trouvèrent irréversiblement liées dans leur interdépendance sur les minerais et les compétences en métallurgie qui étaient inégalement réparties dans l'espace géographique. L'accès à ces ressources cruciales était assuré non seulement via des routes commerciales physiques vers des contrées lointaines, faisant usage de diverses caractéristiques du paysage, tels que les réseaux fluviaux, et des voies construites, mais aussi en créant des réseaux sociaux immatériels, consistant en relations interpersonnelles et en alliances diplomatiques, établies et entretenues grâce à des échanges d'objets extraordinaires (cadeaux). Dans cet article, nous réfléchissons sur ces réseaux de communication de l'âge du bronze et appliquons les résultats d'une analyse de l'usage et de l'usure pour créer de robustes indicateurs de l'ascension et de la chute des réseaux politiques et commerciaux. En conclusion, nous discutons de certaines des forces historiques derrière ce phénomène et des procédés visibles dans les témoignages archéologiques de l'âge du bronze, en Europe et au delà.

\section{ZUSSAMENFASSUNG}

Verbundene Geschichten: Die Dynamik von Interaktion und Handel in der Bronzezeit, 1500-1100 v. Chr., von Kristian Kristiansen und Paulina Suchowska-Ducke

Die Bronzezeit war die erste Epoche, in der sich Gesellschaften auf irreversible Weise miteinander verknüpften durch ihre wechselseitige Abhängigkeit von Erzen und metallurgischen Fertigkeiten, die im geographischen Raum ungleich verteilt waren. Der Zugang zu diesen entscheidenden Ressourcen wurde nicht allein durch physische Handelsrouten über weite Strecken hinweg gesichert, wobei Landschaftsmerkmale wie z.B. Flussnetzwerke, aber auch gebaute Straßen genutzt wurden, sondern auch durch die Schaffung immaterieller, sozialer Netzwerke, die aus interpersonalen Beziehungen und diplomatischen Bündnissen bestanden und durch den Austausch außergewöhnlicher Objekte (Gaben) etabliert und aufrecht erhalten wurden. In diesem Beitrag erörtern wir bronzezeitliche Kommunikationsnetzwerke und wenden die Resultate von Gebrauchsspurenanalysen an, um robuste Indikatoren für den Aufstieg und Fall politischer und wirtschaftlicher Netzwerke zu erzeugen. Schlussfolgernd diskutieren wir einige der historischen Kräfte hinter den Phänomenen und Prozessen, die im archäologischen Befund zur Bronzezeit feststellbar sind, in Europa und darüber hinaus. 


\section{RESUMEN}

Historias conectadas: dinámicas de interacción y comercio durante la Edad del Bronce 1500-1100 BC, por Kristian Kristiansen y Paulina Suchowska-Ducke

En la Edad del Bronce las sociedades quedan, por primera vez, irreversiblemente ligadas debido a su codependencia por los minerales y las actividades metalúrgicas repartidas desigualmente por la geografía. El acceso a estos recursos fundamentales se aseguró no sólo físicamente mediante rutas de comercio a larga distancia, aprovechando elementos del paisaje como las redes fluviales y construyendo caminos, si no también creando redes sociales inmateriales consistentes en relaciones interpersonales y alianzas diplomáticas, establecidas y mantenidas mediante el intercambio de objetos extraordinarios (regalos). En este artículo, reflexionamos sobre las redes de comunicación durante la Edad del Bronce y aplicamos los resultados de los análisis traceológicos para crear indicadores robustos del ascenso y declive de las redes políticas y comerciales. En conclusión, se discuten algunas razones históricas que subyacen a los fenómenos y procesos observables en el registro arqueológico de la Edad del Bronce, en Europa y en otros ámbitos. 